\title{
GALICYJSKA NIEOBYCZAJNOŚĆ KOŃCA XIX I PIERWSZYCH DEKAD XX WIEKU W ŚWIETLE WYBRANYCH DOKUMENTÓW EPOKI
}

\author{
Sylwia Wójtowicz \\ Uniwersytet Wrocławski \\ Wrocław, Polska \\ ORCID: 0000-0001-7309-0682
}

\section{GALICIAN INDECENCY OF THE SECOND HALF OF THE $19^{\mathrm{TH}}$ AND THE BEGINNING OF THE $20^{\mathrm{TH}}$ CENTURY IN THE LIGHT OF SELECTED DOCUMENTS OF THE ERA}

\begin{abstract}
The article deals with the issue of indecency in the second half of the 19th and the beginning of the 20th century in Eastern Galicia. Fornication, prostitution, women and children trafficking, white slavery are called indecency. Common for Eastern Galicia prostitution was neither resulting from the dynamic industrialisation processes nor from spectacular urbanization, unlike in Western Europe. Galicia, which has been part of the Habsburg Empire since 1772, was condemned to internal political conflict, economic slump and backwardness due to its parochial nature. Pervasive poverty, pushing the population to migration, generated such destructive social phenomena as homelessness, violence, orphanhood and prostitution. In this respect, Galicia shared the fate of other colonised lands of Central and Eastern Europe, from where traders usually recruited their victims. The problem has not dissapeared after the collapse of central countries, it constituted a serious challenge for the authorities of the Second Polish Republic, which in 1918 included Eastern Galicia. The inspiration to write the text was found in the Historical Archive of the City of Lviv, in the correspondence of Andrzej Szeptycki, the Metropolitan of the Greek Catholic Church and in the series of articles by the Ukrainian prose writer Jurij Wynyczuk entitled From the history of the Ukrainian bottom.
\end{abstract}

Key words: indecency, prostitution, human trafficking, women and children trafficking, white slavery, Eastern Galicia, Ukrainian literature, archival correspondence, documents of the era, Andrzej Szeptycki

„,Jest upalny czerwiec. Do zaginionej w Karpatach stacyjki pociagi docieraja ze wzruszajaca austrowęgierska punktualnościa. Z ostatniego wagonu wyskakuje młody oficer. Masy upalnego powietrza drża nad tonaca $w$ winorośli architekturą. Hotel, ratusz, burdel, koszary. Lazaret. Kurwy czułe jak siostry i siostry piękne jak kurtyzany. Z otwartych okien ptynie lekcja muzyki. Ubita droga nadciagaja wozy cyrkowe. Stychać daleki, niewyraźny krzyk. Chryste Panie, jadę tam!’. 
Nieobyczajność w odniesieniu do niemoralnego, nieprzyzwoitego czy wyuzdanego zachowania to dla historyka literatury temat z pewnością intrygujący oraz inspirujący, bo też jest to zagadnienie atrakcyjne literacko, kulturowo i historycznie, niezależnie od sposobu jego wartościowania, choć - jak pokazuje stan badań nad tytułowym problemem, szczególnie badań ukrainoznawczych ${ }^{1}$ - wciąż oczekuje na odpowiednie poszukiwania naukowe i pogłębioną analizę $e^{2}$. „Dla badacza literatury druga połowa wieku XIX i jeszcze początek XX jest epoką powieści”3 - nie bez racji pisze Małgorzata Czermińska. Już z pobieżnego przeglądu „klasycznej” prozy ukraińskiej tamtego czasu można wysnuć wniosek, że kwestia nieobyczajności nie jest tematem jej zupełnie obcym. Obyczajowo-psychologiczna powieść Pana Myrnego ${ }^{4}$ o znamiennym tytule Nierząnica (Повiя, wydana w dwóch tomach w latach 1883-1884, a w całości - dopiero w 1928 r.) z pewnością potwierdza tę konstatację. Nie potwierdza jednak reguły. Podobnie jest w przypadku twórczości pisarza reprezentującego środowisko pisarzy galicyjskich - Iwa-

$1 \quad$ Z obserwacji wynika, że problem nieobyczajności, który w niniejszej publikacji będzie nazywany również nierządem, prostytucją, handlem żywym towarem (kobietami i dziećmi), handlem ludźmi czy białym niewolnictwem, nie był przedmiotem szczególnych badań ukrainoznawców, zwłaszcza historyków literatury. W sposób nieznaczny lukę te uzupełniają badania historyczne, np. praca Illi Barkowa. Patrz: I. Барков, Інститут проституиї в містах південної України в 1843-1914 рр. Запоріжжя 2018; [w:] Zaporoski Uniwersytet Narodowy, [źródło internetowe:] http://phd.znu.edu.ua/page/dis/01_2018/Barkov_dis.pdf, dostęp: 10.02.2020. Wskazana praca nie koncentruje się jednak na terenie Galicji.

2 Należy się zastrzec, że niniejszy artykuł nie rości sobie pretensji do wyczerpania tematu. Jest bardziej próbą zasygnalizowania, że problem nieobyczajności mocno dotykając całą społeczność Galicji, musiał dotknąć również społeczność ukraińską. Konstatację tę po części potwierdzają wybrane dokumenty epoki, nawet jeśli w swojej treści nie zawsze odnoszą się bezpośrednio do ludności ukraińskiej. Z uwagi na fakt, że nie udało mi się dotrzeć do odpowiedniej ukraińskiej literatury przedmiotu (poza nielicznymi wyjątkami), dochodzę do wniosku, że tytułowy problem w literaturoznawstwie ukraińskim jest jeszcze mało znany, a ze względu na „niewygodny” charakter pewnie też tabuizowany. Z tego względu zdecydowałam się opatrzyć artykuł obszerną częścią wstępną, ukazującą skalę problemu nierządu u schyłku XIX wieku i pierwszych dekadach XX wieku w Europie, następnie Galicji. Stąd też w tytule artykułu tak szerokie ramy czasowe, mimo że inspiracją do podjęcia przeze mnie rozważań nt. galicyjskiej nieobyczajności były przede wszystkim ego-dokumenty w postaci korespondencji Metropolity Szeptyckiego z początku lat 30. XX wieku. Podczas ich omawiania posiłkuję się przede wszystkim z materiałami polskimi oraz niewielką liczbą publikacji ukraińskich. Wśród tych ostatnich interesujące informacje nt. nierządu w Galicji prezentuje popularno-naukowa seria artykułów ukraińskiego pisarza Jurija Wynnyczuka. Zob.: Ю. Винничук, Таємниці львівського дна. (за мемуарами й матеріалами поліції та львівської преси початку XX cm.), cz. I, II, III, [w:] https://zbruc.eu/node/27795, dostęp: 15.07.2019.

3 M. Czermińska, Autobiograficzny trójkąt. Świadectwo, wyznanie $i$ wyzwanie, Kraków 2000, s. 12.

$4 \quad$ Panas Myrnyj to pisarz wywodzący się z Ukrainy Naddnieprzańskiej i ukazujący w swoich utworach problemy Ukraińców tamtego regionu. 
na Franki. W jego nader imponującym dorobku pisarskim znajdujemy jeden utwór pt. Dla ogniska domowego (1892), który poświęcony jest problemowi nieobyczajności. W centrum uwagi twórców ukraińskich $\mathrm{z}$ obu stron rzeki Zbrucz $^{5}$ - hołdujących przeważnie idei narodnickiej - znajdujemy zazwyczaj rozbudowaną refleksję odautorską nt. statusu społecznego, ekonomicznego, politycznego i kulturowego Ukraińców, którym w drugiej połowie XIX i początku XX wieku przyszło żyć w graniach dwóch wielkich imperiów: Rosji i Austrii. Nadzieję na zmianę ukraińskiego statusu geopolitycznego przyniosła I wojna światowa, która przyczyniając się do klęski militarnej mocarstw, dała Ukraińcom asumpt do podejmowania działań na rzecz uzyskania niezależności narodowo-politycznej i utworzenia własnego państwa. Ukraińcy galicyjscy, nazywani wówczas przeważnie Rusinami, swoje państwowotwórcze marzenia realizowali w walce z Polakami o sporne tereny Galicji Wschodniej, która miała być terytorialną podstawą państwa o nazwie Zachodnioukraińska Republika Ludowa (ZURL). Krótką, niespełna roczną jego historię (01.11.1918 - 16.07.1919) zakończyła wygrana strony polskiej, a Galicja Wschodnia weszła w skład odrodzonego państwa polskiego. Jej obecność w granicach II Rzeczpospolitej ostatecznie została przypieczętowana w 1923 r. przez Radę Ambasadorów, przynosząc fiasko ukraińskich działań dyplomatycznych za granicą, jak i stosowanej w regionie polityki negacji polskiego aparatu państwowego. Dwudziestoletnie burzliwe współistnienie Ukraińców i Polaków w obrębie II RP było destrukcyjnym dla obu stron stanem ciągłych walk na słowa (nierzadko też czyny) zarówno w sferze polityki oficjalnej, jak i na poziomie życia społeczno-politycznego w regionie. Wobec bieżących problemów politycznych i społecznych, a wraz z nimi „wysokich” dylematów moralnych, wstydliwy problem nieobyczajności narodu ukraińskiego schodził, jak się wydaje, na plan dalszy. W dyskursie literackim pojawiał się więc przeważnie mimochodem, przy okazji podejmowania innych ważkich problemów czasu.

Kiedy literatura milczy, przemawiają dokumenty. Badaczowi literatury przychodzi więc korzystać $\mathrm{z}$ dokumentów epoki w postaci tekstów usytuowanych na literackich peryferiach, na styku literatury $\mathrm{z}$ historią. Będą to teksty kultury w postaci literatury niefikcjonalnej, jak np. wypowiedzi publicystyczne. Będą to również ego-dokumenty w postaci korespondencji, która okaże się cennym i nierzadko unikatowym materiałem źródłowym zaświadczającym o epoce i ludziach ją współtworzących, który dziś zazwyczaj stanowi własność archiwalną lub muzealną. Taką też wartość mają dla rozważań zaprezentowanych $\mathrm{w}$ niniejszym tekście dokumenty pozyskane podczas kwerendy w Archiwum Historycznym miasta Lwowa, znajdujące się w zespole dokumentów Andrzeja Szeptyckiego - metropolity Kościoła greckoka-

\footnotetext{
$5 \quad$ Na rzece Zbrucz przebiegała granica między Austrią i Rosją.
} 
tolickiego ${ }^{6}$. Trzeba dodać, że omawiany w kontekście tytułowego problemu materiał archiwalny wychodzi poza kanon prywatności, bowiem składają się na niego nie tyle listy osobiste, ile oficjalne, służbowe ${ }^{7}$ (jak by powiedział Paul Ricoeur: „dokumenty dokumentalne”) w postaci m.in. sprawozdań, raportów, zaproszeń, podziękowań, próśb (np. o wstawiennictwo za osoby skrzywdzone, potrzebujące pomocy), petycji czy listów otwartych - protestów, listów polecających, listów komentujących trudną sytuację społeczną lub polityczną. Zgromadzona korespondencja nie tylko w sposób zaskakujący zaświadcza czy też przypomina swoją treścią o przeszłości, nie zawsze łatwej, i jak się okazuje, niekiedy też mało chwalebnej, lecz mimo wszystko składającej się na całość obrazu społeczeństwa galicyjskiego, którego niebagatelny (jeśli nie największy) odsetek w drugiej połowie XIX i początku XX wieku stanowiła ludność rusko-ukraińska ${ }^{8}$. Obszerne epistoły - zazwy-

6 Obecność metropolity Szeptyckiego w dyskusji nt. galicyjskiej nieobyczajności nie powinna budzić zdziwienia. Szeptycki jako najwyższy rangą duchowny greckokatolicki - a przy tym majętny przedstawiciel starego rodu szlacheckiego o korzeniach ruskich, obdarzony charyzmą erudyta, wytrawny znawca sztuki i filantrop - przez długi okres sprawowania swojej funkcji metropolity (w latach 1900-1944 arcybiskup metropolita lwowski i halicki, biskup kamieniecki) pozostawał jedna z najważniejszych postaci w gronie ukraińskiej elity galicyjskiej tamtego czasu, doskonale zdajac sobie z sprawe $\mathrm{z}$ trudnego położenia ,wybranego przez siebie narodu". Należy przypomnieć, że rodzina Andrzeja Szeptyckiego od dwóch pokoleń była już rodziną polską i rzymskokatolicką. Korzenie ruskie Szeptycki odziedziczył po ojcu Janie Kantym Szeptyckim. Matka metropolity - Zofia Szeptycka - była córką znanego polskiego komediopisarza Aleksandra Fredry. Wstępując do Zakonu Bazylianów, Szeptycki dokonał konwersji religijnej i został przewodnikiem duchowym Rusinów, którzy z czasem zaczną nazywać siebie Ukraińcami. Duchowny wziął na siebie ciężar nie tylko reprezentowania swoich wiernych w sferze religijnej, ale również wspierania ich (częstokroć materialnie, instytucjonalnie) w życiu społecznym, politycznym i kulturalnym. Jego szeroko zakrojone działania prospołeczne, obliczone na poprawę jakości życia ubogich nie obejmowały swoim zasięgiem wyłącznie ludności ruskiej, choć z pewnością z uwagi na nią były podejmowane. Szeptycki - jak pokazuje korespondencja - starał się reagować w miarę swoich możliwości finansowych, zdrowotnych i organizacyjnych na wszystkie kierowane do niego prośby. Informacje dotyczące biografii metropolity można znaleźć w wielu materiałach naukowych i popularnonaukowych, ograniczę się do padania kilku pozycji w języku polskim. Zob. m.in.: Zakrzewski Bogdan, Mój Syn Metropolita Szeptycki. Młodość i powołanie o. Romana Andrzeja Szeptyckiego zakonu św. Bazylego Wielkiego, wyd. Zakład Narodowy im. Ossolińskich, Wrocław 1993; M. Nowak, Szeptycki Roman Aleksander w zakonie Andrzej (1865-1944), [w:] Polski slownik biograficzny, t. 48/2, z. 197, Warszawa 2012, s. 216-224; St. Łoś, Sprawa ukraińska, wybór pism pod red. nauk. M. Marszała, S. Wójtowicz, Kraków 2012, s. 73-78; Szeroką informację nt. prac polskich i ukraińskich traktujących o życiu i działalności Andrzeja Szeptyckiego podaje Magdalena Nowak. Zob.: M. Nowak, Refleksje o pracy badawczej nad monografia o metropolicie Andrzeju Szeptyckim, [w:] Biografistyka we wspótczesnych badaniach historycznych. Teoria i praktyka, pod red. J. Kolbuszewskiej, R. Stobieckiego, Łódź 2018, s. 151-152.

Czasami bardzo cienka jest granica między jednymi a drugimi.

8 Opinie polskie i ukraińskie dotyczące konkretnych liczb są rozbieżne. Strona ukraińska posługuje się zazwyczaj danymi pochodzącymi z austriackiego spisu z 1910 r., opartego na 
czaj adresowane do Szeptyckiego ${ }^{9}$ - mają również walor biograficzno-poznawczy ${ }^{10}$. Okazują się bowiem doskonałym materiałem faktograficznym, potwierdzającym szerokie spektrum zainteresowania ukraińskiego duchownego problemami społeczno-politycznymi tamtego czasu. Wskazują - poprzez katalog nadawców, przesiąknięty estymą ton i odpowiednią tytulaturę - na jego pozycję zarówno w środowisku ukraińskim, jak i polskim. Należy zatem przyznać rację Czermińskiej, która twierdzi, że listy zajmują miejsce szczególne w nienapisanych autobiografiach osób, których życie autobiografii by się domagało ${ }^{11}$. Tak jest z pewnością w przypadku postaci ukraińskiego duchownego. Niezależnie więc od motywacji powstawania i mechanizmów działania współczesnych ukraińskich archiwów i muzeów (państwowych, społecznych, prywatnych), instytucje te okazują się istotnymi miejscami pamięci i niejednokrotnie jedynymi depozytariuszami fragmentu przeszłości narodu ukraińskiego ${ }^{12}$. „Archiwizujcie, archiwizujcie! Zawsze coś zostanie!” - nawoływał Pierre Nora. Zawołanie francuskiego badacza z pewnością nabiera pozytywnego potwierdzenia $\mathrm{w}$ odniesieniu do postkolonialnej i posttotalitarnej rzeczywistości ukraińskiej, która wciąż potrzebuje odtwarzania pamięci historycznej i oczyszczania jej z ideologicznego zbrukania. Dotyczy to zarówno pamięci jednostkowej, jak i zbiorowej (ukraińskiej) oraz regionalnej (galicyjskiej). Zatem lektura archiwaliów pozwala nam być bliżej lu-

kryterium językowym. Według uzyskanych wówczas danych Polacy stanowili w całej Galicji 47,6\% ludności, Ukraińcy 40,3\% i Żydzi 10,9\%. W Galicji Wschodniej, która obejmowała około $70 \%$ administracyjnego obszaru całej Galicji, proporcje te kształtowały się w sposób następujący: Ukraińcy stanowili 71,1\% ogółu ludności, Polacy 14,4\% i Żydzi 12,4\%. Dane te odbiegają od tych danych, które zostały zgromadzone w II RP podczas pierwszego powszechnego spisu ludności z 30 września 1921 r., według którego w Galicji (Małopolsce) Wschodniej było 53,7\% Ukraińców i 39,1\% Polaków. Wobec rozbieżności interpretacyjnych rację chyba należy przyznać Henrykowi Cimkowi, który podsumowując powyższe dane pisze: „Uwzględniając skomplikowane stosunki narodowościowe w Galicji Wschodniej i dyskusyjną wiarygodność poszczególnych spisów, można jedynie stwierdzić, że na tych terenach ludność rusińska (ukraińska) przeważała nad ludnością polską". Zob.: H. Cimek, Przynależność Galicji (Małopolski) Wschodniej - w koncepcjach polskich klubów ludowych w 1919 r., „Polityka i Społeczeństwo” 2008, nr 5, s. 11.

9 Archiwalna korespondencja to przede wszystkim listy adresowane do Szeptyckiego. $\mathrm{Z}$ rzadka pojawiają się listy przez niego pisane. Jeśli już, to są to krótkie odpowiedzi w postaci podziękowania za list.

10 Zaprezentowane w artykule rozważania nt. listów mają przede wszystkim charakter historyczny, dlatego też w narracji pojawi się szkic biograficzny, kontekst historyczno-społeczny oraz edytorski. Pojawią się również uwagi ogólne na temat poszczególnych adresatów korespondencji oraz tematyki bloku listów. Zastosowana metodologia odwołuje się głównie do narzędzi historycznych (analiza dokumentu źródłowego, badania archiwalne) oraz historyczno-opisowych związanych z epoką.

${ }_{11}$ M. Czermińska, Autobiograficzny trójkąt. Świadectwo, wyznanie i wyzwanie..., s. 74.

12 Zob. M. Wiśniewska, Archiwum jako miejsce pamięci, „Archiwa - Kancelarie - Zbiory” 2013, nr 4 (6), s. 137-148. 
dzi w historii ${ }^{13}$ i tym samym uzupełniać wiedzę na temat różnych sfer życia przeszłych pokoleń, w tym - co istotne - także sfery odnoszącej się do niewygodnego problemu nieobyczajności.

\section{KONTEKST EUROPEJSKI}

Narody europejskie, szczególnie zachodnioeuropejskie, dysponujące dużo większymi zasobami źródłowymi (tak literackimi, historycznymi, jak i (ego)-dokumentalnymi) oraz odpowiednio wypracowaną literaturą przedmiotu nt. zjawiska nieobyczajności, już odrobiły tę lekcję ${ }^{14}$. Pisarze poszczególnych epok ujmowali temat najczęściej w sztafażu aktualnie dominującego stylu. Korzystając $\mathrm{z}$ odpowiednich narzędzi genologicznych i modnych środków wyrazu, budowali obraz literacki zgodny z własnym światopoglądem. Ten zaś nakazywał im ocenić problem nieobyczajności zazwyczaj negatywnie. Jednak do XIX stulecia nie był to temat nadmiernie przykuwający uwagę także i pisarzy europejskich. Zdecydowany wzrost trwającego do dziś - ze zmiennym natężeniem - zainteresowania kategorią nieobyczajności - ujmowanej już nie w sposób eufemistyczny poprzez wyszukaną metaforę czy symbol, ale nazywany wprost procederem nierządu, prostytucji, „białym niewolnictwem” (jak pisano w krajach anglosaskich) czy też „handlem żywym towarem” (jak przyjęto w polskiej literaturze przedmiotu) - przypada właśnie na XIX wiek, szczególnie jego drugą połowę, oraz początek XX wieku ${ }^{15}$. Jest to czas definiowany przede wszystkim przez dwie rewolucje: francuską i przemysłową.

13 Zob.: W. Szulakiewicz, Ego-dokumenty i ich znaczenie w badaniach naukowych, „Przegląd Badań Edukacyjnych” 2013, nr 16, s. 65.

14 Problem nieobyczajności w postaci handlu żywym towarem dotykał kraje rozwinięte, a więc kraje Europy Zachodniej, które w porównaniu z krajami w Europie Środkowo-Wschodniej nie przeżywały tak dużych kryzysów gospodarczych i problemów wewnętrznych. Zamieszkałe jednak były przez kobiety i dzieci stanowiące obiekt pożądania przestępców. Ich ofiarami padały więc kobiety i dzieci z Francji, Niemiec, Austrii, Szwajcarii. Radosław Antonów, autor monografii Drogi hańby. Piśmiennictwo polskie przełomu XIX i XX wieku o handlu „żywym towarem”, pisze: „Handel ludźmi, jako pokłosie handlu niewolnikami zaczął być traktowany jako przestępstwo i od połowy XIX wieku był zwalczany na wielu płaszczyznach - od prawnej przez polityczną po społeczną i moralną. Przestępstwo to stało się również przedmiotem badań naukowych, których początki w krajach Europy Zachodniej sięgają połowy XIX wieku i wiążą się pierwotnie przede wszystkim z badaniami nad prostytucją, jej przyczynami i skutkami”. Zob.: R. Antonów, Drogi hańby. Piśmiennictwo polskie przełomu XIX i XX wieku o handlu „żywym towarem”, Wrocław 2013, s. 13-14.

15 Warto zauważyć, że do I wojny światowej handel żywym towarem w odniesieniu do handlu kobietami był definiowany jako handel wartościami płciowymi, lub też razem z nimi i osobą, jakiejś kobiety. Zob.: D. Dulak, Handel ludźmi w II Rzeczpospolitej, „Poliarchia” 2016, nr 2 (7), s. 6. Por.: A. Wróblewski, O prostytucji i handlu kobietami; Handel Kobietami; Handel Kobietami na Wegrzech; Wskazane prace znajdują się w wyborze źródeł pod red. R. Antonowa: 
Mimo, że pierwsza miała miejsce u schyłku XVIII stulecia, to istotnie wpłynęła na zmiany światopoglądowe przyszłych pokoleń. Stąd nie będzie przesadą stwierdzenie, że obie rewolucje diametralnie odmieniły oblicze XIX wiecznej Europy, generując zmiany w sferze politycznej, społecznej oraz ideologicznej i mentalnej. Symbolem nowych czasów okazał się niebywały jak dotąd postęp $\mathrm{w}$ nauce, a w ślad za nim postęp w dziedzinie techniki, medycyny, komunikacji, industrializacji, urbanizacji oraz wszystkich sfer kultury, w tym - co oczywiste - literatury. Patrząc na skalę rozwoju, z pewnością można powiedzieć, że był to czas uprawniający Wilhelma II - wielkiego orędownika nowoczesności i wynalazczości - do nazwania wieku XIX ,stuleciem wspaniałych czasów". Wspaniałe czasy promieniowały swoimi osiągnięciami na pierwsze dekady XX wieku. Pokolenie korzystające z dobrodziejstw cywilizacyjnych i pozostające pod niewątpliwym urokiem tego okresu - który uznany został wręcz za całą epokę - znalazło dla niego nobilitującą nazwę La Belle Époque.

Nie wszyscy jednak pozostawali w zachwycie wobec osiągnięć opisanej epoki. Uroku swoich czasów z pewnością nie zauważały najniższe warstwy społeczne. To z nich wywodziły się ofiary rewolucyjnych przemian wskazanego okresu. Należy bowiem przypomnieć, że - oprócz spektakularnych sukcesów - wiek pary i elektryczności obfitował również w mniej chętnie przywoływane patologiczne zjawiska, jak wszechobecna wśród przedstawicieli niższych warstw społecznych nędza, głęboka nierówność społeczna oraz towarzyszący jej nieograniczony wyzysk. Nieograniczony wiekiem, płcią, czy szerokością geograficzną ${ }^{16}$. Morderczą pracę bez jakiejkolwiek ochrony socjalnej wykonywały ubogie dzieci, kobiety oraz mężczyźni we wszystkich częściach nie tylko Europy, ale i całego Świata. To jedna z form powszechnego wówczas wyzysku, który wkrótce miał się przyczynić do wielkiego kryzysu przełomu wieków. Ten z kolei zaowocował radykalnymi ruchami społeczno-politycznymi dającymi impuls wojnie ${ }^{17}$. Innym dotkliwym problemem

Drogi hańby. Piśmiennictwo polskie przełomu XIX i XX wieku o handlu ,żywym towarem, op. cit., s.105-142.

16 W jednej ze współczesnej publikacji na ten temat czytamy: „Siedmiolatek, narażający swoje życie podczas czyszczenia kominów. Ośmiolatka, pracująca jako gospodyni domowa. I sześciolatki w kopalniach. Bez udziału dzieci dziewiętnastowieczna rewolucja przemysłowa mogłaby w ogóle nie dojść do skutku.[...] Dzieci. Nie mają prawa głosu. Nie mają wyboru. Dorośli posyłają je do najcięższych prac. Nikogo to nie dziwi." Cytat pochodzi z artykułu promującego książkę Katarzyny Nowak pt. Dzieci rewolucji przemysłowej . Patrz: Dzieci rewolucji przemysłowej. Kto naprawdę zbudowat wspótczesny świat? [w:] „TwojaHistoria.pl”, [źródło internetowe:] https://twojahistoria.p1/2019/07/09/dzieci-rewolucji-przemyslowej-kto-naprawde-zbudowal-wspolczesny-swiat/, dostęp: 02.12.2019.

17 „Wielka Wojna, a także wszystko co się stało po jej zakończeniu, była pokłosiem rewolucji przemysłowej, imperializmu, polityki kolonialnej, przemian kulturowych i ideologicznych. Świat goniący za mitycznym postępem, wypełniający się pragnącymi samostanowienia narodami, wstrząsany konfliktami społecznymi, balansujący między skrajną biedą, a bogactwem, nie 
społecznym, inną formą wyzysku - tyleż powszechną, co przemilczaną czy wręcz tolerowaną, jak pisze Jolanta Sikorska-Kulesza w pracy Zło tolerowane (2004) - był proceder handlu żywym towarem, najczęściej kobietami i dziećmi. Powołując się na liczne dokumenty Kulesza przyjmuje tezę, że XIX wiek był wiekiem ekspansji prostytucji: „Domy publiczne oraz uliczne prostytutki stały się integralnym elementem pejzażu kapitalistycznego miasta. Liczba kobiet oferujących usługi erotyczne w europejskich metropoliach - w Londynie, Paryżu, Berlinie, Petersburgu, a nawet w Warszawie - zdaniem ówczesnych obserwatorów szła w dziesiątki, a nawet setki tysięcy"18. Badaczka dodaje, że proceder nierządu z powodzeniem rozwijał się także w poprzednich stuleciach, jednak dopiero XIX-wieczne realia - jak nigdy wcześniej - sprzyjały rozwojowi handlu żywym towarem ${ }^{19}$.

Literatura, będąc papierem lakmusowym epoki, nie mogła przejść obojętnie obok palących problemów czasu. Reagowała więc zarówno na blaski, jak i cienie epoki nowożytnej. Realiści i naturaliści piętnujący patologiczne zjawiska społeczne drugiej połowy XIX wieku ostrze swojego pióra celowali również w proceder nierządu. Aleksander Dumas (syn), Joris-Karl Huysmans, bracia Edmond i Jules de Goncourt, Émile Zola, Guy de Maupassant, Lew Tołstoj, Fiodor Dostojewski, Aleksander Kuprin oraz wielu innych uczynili bohaterkami swoich powieści kobiety lekkich obyczajów, umieszczając je, jak np. Zola w Nanie, w centrum uwagi społecznejej. Plejadę twórców europejskich z pewnością można uzupełnić o nazwisko Panasa Myrnego, przywołując jego powieść Nierzadnicę. Przy czym zarówno powieść Myrnego, jak i wspominany już, dużo mniejszy utwór Iwana Franki Dla domowego ogniska należy rozpatrywać - mając na uwadze ich cały dorobek pisarski oraz osiągnięcia literatury rodzimej tamtego czasu - raczej w kategoriach wyjątku. W Europie interesujący stosunek do nieobyczajności przyniósł przełom XIX i XX stule-

wytrzymał napięcia czego efektem były dwa krwawe konflikty i dwa totalitaryzmy". S. Adamkiewicz, Najcudowniejszy wiek XIX?, [w:] „Histmag.org”, [źródło internetowe:] https://histmag.org/Najcudowniejszy-wiek-XIX-14784, dostęp: 10.02.2020.

18 J. Sikorska-Kulesza, Zło tolerowane. Prostytucja w Królestwie Polskim w XIX wieku, Warszawa 2004, s. 5.

19 „Rozległe i szybkie procesy uprzemysłowienia oraz urbanizacji zachodzace w XIX w. w Europie w niebywałym tempie poszerzały obszary nędzy, której częścią składową była armia kobiet pozbawionych możliwości utrzymania się, skazana niejako na prostytucję. Z drugiej zaś strony te same procesy ekonomiczne $\mathrm{i}$ ich następstwa społeczne, a także pewne zjawiska kulturowe (zwłaszcza odmienne normy życia seksualnego mężczyzn i kobiet), wytworzyły większe zapotrzebowanie na komercyjny seks i większą niż wcześniej liczbę potencjalnych klientów prostytutek. [...] Organizacja prostytucji zaczęła nabierać iście kapitalistycznego rozmachu. W jakimś sensie ta sfera interesów przeszła w XIX w. drogę z manufaktury do globalnego biznesu, realizowanego w postaci międzynarodowego, zorganizowanego handlu kobietami w celach nierządu [...]". Zob. J. Sikorska-Kulesza, Zło tolerowane..., s. 5-6.

20 Ibidem, s. 7. 
cia wraz z modernizmem promującym hasło wolności we wszystkich sferach życia, w tym również w sferze seksualnej. Kobiecy głos - coraz lepiej słyszalny dzięki ruchowi feministycznemu - coraz mocniej upominał się o prawo kobiet do emancypacji. Należy się spodziewać, że głoszone pod koniec XIX w. hasło wolności seksualnej nie było jednak zgodą na „białe niewolnictwo”. Kobiety wszystkich orientacji politycznych próbowały (mimo ograniczeń społecznych, finansowych czy kulturowo-mentalnych) przeciwdziałać procederowi nierządu, którego były przecież najczęstszymi ofiarami. „Kobiety domagały się - pisze Julita Świst w artykule pt. Prostytucja - rys historyczny - tych samych praw, co mężowie w instytucji małżeństwa, czyli wierności oraz czystości obyczajów. Feministki zwalczały podwójną moralność, opinię mężczyzn o konieczności istnienia prostytucji. Wykazywały, że źródłem jej jest upośledzenie kobiety - brak możliwości edukacji, dopuszczenie swobody seksualnej mężczyzn i potępienie za nią kobiet" ${ }^{21}$. W tym samym czasie część mężczyzn przerażonych emancypacją kobiet wykreowała, jak sugeruje Maria Podraza-Kwiatkowska, literacką postać kobiety fatalnej ${ }^{22}$. Niewiele miała ona wspólnego z rzeczywistością, a właściwie z jej najciemniejszą stroną, gdzie - jak pokazują dokumenty - nierząd przybrał formę wyjątkowo brutalnego, masowego - jeśli patrzeć na jego skalę - i wręcz zinstytucjonalizowanego zjawiska, jakim był handel żywym towarem. Rozumieli to wszyscy (niezależnie od prezentowanej płci czy poglądów społeczno-politycznych) włączający się wówczas do walki z tym zjawiskiem.

\section{ZJAWISKO NIEOBYCZAJNOŚCI W REGIONIE WSCHODNIO-GALICYJSKIM}

Hasła głoszone przez europejskie emancypantki pod koniec XIX wieku znalazły podatny grunt $\mathrm{w}$ środowisku kobiet polskich, żydowskich i ukraińskich na terenie Galicji. Tutaj, podobnie jak w Europie Zachodniej, głównymi orędownikami ich spraw byli socjaliści ${ }^{23}$. Galicyjskie kobiety włada-

\footnotetext{
21 J. Świst, Prostytucja - rys historyczny, [w:] „Racjonalista.pl”, [źródło internetowe:] http:// www.racjonalista.pl/kk.php/s,4028/k,2, dostęp: 16.07.2020.

22 Zob. M. Podraza-Kwiatkowska, Symbolizm i symbolika w poezji Młodej Polski, Kraków 2001, s. 274-76.

${ }^{23}$ Wśród polskich socjalistów wypada wskazać na Ignacego Daszyńskiego, który - jak twierdzi Ryszard Tommczyk - głosił w ślad za lewicą galicyjską nie tylko postulat reformy prawa małżeńskiego i wprowadzenia świeckich rozwodów, ale również „,wolnej miłości”. Z kolei wśród ukraińskich socjalistów wspierających rodzimy ruch kobiecy z pewnością należy wymienić przedstawicieli frakcji radyklanej przede wszystkim Iwana Frankę i Mychajła Pawłyka, ale również Cyryla Trylowskiego. Ten ostatni - jak pisze Tomczyk - „Jako przykład podawał Hucułów, zwolenników swobodnych kontaktów męsko-damskich. Na Huculszczyźnie wśród mężczyzn rozpowszechnione było posiadanie „lubaski” (kochanki). Również Hucułki, które posiadały pewien majątek i miały lepszą sytuację finansową, wyrzucały z domu męża, gdy był
} 
jące piórem próbowały na wzór europejskich koleżanek poruszać problem kobiecej wolności, w tym również związanej ze sferą seksualną. Wskazana problematyka mniej lub bardziej śmiało pojawiała się w wypowiedziach literackich i publicystycznych autorstwa pisarek ukraińskich z Galicji m.in.: Natalii Kobrynskiej (była animatorką instytucjonalnego ruchu kobiet ruskich, który w 1884 rozpoczął działalność pod szyldem Towarzystwa Ruskich Kobiet), poetki Uljany Krawczenko czy wreszcie muzy ukraińskich modernistów z Galicji - pisarki Olgi Kobylanskiej ${ }^{24}$. Zaangażowane w ruch kobiecy działaczki ruskie (z początkiem XX wieku będą nazywane już ukraińskimi) podejmowały też szereg innych doniosłych postulatów: nagłaśniały prawo do godnego życia i upodmiotowienia kobiet, prawo do wolności socjalnej (w tym m.in. prawo do edukacji, zarobkowania, a więc wyzwolenia spod „opieki” mężczyzny), z czasem zaczęły podnosić też postulat wolności narodowej. W swoich poglądach ideologiczno-politycznych nie były jednak monolitem. Nie wszystkie współpracowały ze środowiskiem socjalistów, cześć próbowała realizować głoszone hasła we współpracy z przedstawicielami ruchu narodowego i konserwatywnego, którzy również upominali się o prawo do edukacji i ochrony socjalnej wszystkich Ukraińców, prezentowali też aspiracje niepodległościowe. Głos w wymienionych sprawach zabierał z pozycji autorytetu cerkiewnego również Andrzej Szeptyckii ${ }^{25}$, który u schyłku XIX wieku został biskupem stanisławowskim Kościoła greckokatolickiego, po czym od 1900 roku zasiadał na lwowskim tronie metropolitalnym, sprawując posługę arcybiskupią do roku 1943.

Mimo rozbieżności światopoglądowych liderom i liderkom ukraińskiego życia publicznego tamtego czasu zależało na poprawie kondycji społeczeństwa ukraińskiego, które pod panowaniem Habsburgów doświadczało wielu destrukcyjnych społecznie zjawisk. Jednym z nich z pewnością był zakrojony

dla nich niedobry, lub wiązały się z kimś innym. Wśród gaździn huculskich było dużo takich, które nie były stałe w uczuciach i miały kochanków, często młodszych od siebie. W wielu miejscowościach huculskich panna z dzieckiem nie była obiektem tak dużych szykan, jak w innych regionach Galicji. W rozpowszechnionym poglądzie kobieta musiała mieć dużo dzieci (mniej ważne było, czy pochodzą one z prawego łoża, czy też są pozamałżeńskie). Jeżeli miała mało dzieci lub nie miała ich wcale, popełniała grzech. Moralność na Huculszczyźnie nie miała przy tym znamion rozwiązłości obyczajów i zepsucia, ale wynikała z historycznej miejscowej tradycji. Liberalny stosunek do wierności małżeńskiej występował $\mathrm{w}$ różnych europejskich etnokulturach i warstwach społecznych, nawet dość odległych od Galicji”. Zob.: R. Tomczyk, Rusinki (Ukrainki) w autriackiej Galicji. Między konserwatyzmem a radykalizmem, „Przegląd Zachodniopomorski” 2012, t. XXVII, z. 2: Kobieta w kulturze politycznej świata, s. 102-103.

${ }_{24} \quad$ Więcej nt.: R. Tomczyk, Rusinki (Ukrainki) w autriackiej Galicji.., op. cit., s. 89-111.

25 Szeptycki wystosował wówczas wiele listów adresowanych zarówno do duchownych obrządku greckokatolickiego, jak i wiernych. Zob. m.in.: Митрополит Андрей Шептицький. Життя і діяльність. Документи і матеріали 1899-1944, t. II: Церква і иуспільне питання, ks. 1, red. А. Кравчук, Львів 1998. 
na szeroką skalę proceder nierządu. Ryszard Tomczyk zauważa, że popularyzacja swobody seksualnej przez środowiska lewicowe i liberalne końca XIX w. zbiegła się w Galicji z nagłośnieniem problemu handlu żywym towarem przy okazji słynnego lwowskiego procesu grupy szmuglerów, którzy pod koniec lat 80 . sprzedali na światowym rynku prostytucji 23 młode Galicjanki ${ }^{26}$. Handel ludźmi był w prowincji galicyjskiej tamtego czasu zjawiskiem dość powszechnym, jak twierdzą autorzy prac dokumentujących zjawisko nierządu. Proceder ten na terenie Galicji nie był jednak wynikiem dynamicznych procesów uprzemysłowienia czy spektakularnej urbanizacji jak w Europie Zachodniej. Ziemia galicyjska, wchodząca od 1772 r w skład imperium Habsburgów ${ }^{27} \mathrm{z}$ uwagi na prowincjonalny oraz graniczny ${ }^{28}$ charakter skazana była przez lata zaborów na polityczny konflikt wewnętrzny, zastój gospodarczy i zacofanie. Powszechnie znane powiedzenie o "galicyjskiej nędzy" 29 miało swoje uzasadnienie w zaborowej rzeczywistości, co potwierdza w swoich licznych pracach historycznych ukraiński historyk Jarosław Hrycak. W jednej z nich czytamy: ,są na mapie miejsca, których mieszkańcy przegrywają już w chwili narodzin. W XIX wieku jednym z takich miejsc była Galicja. Ten, kto pragnął bogactwa i sławy lub po prostu spokojnego i w miarę dostatniego życia dla siebie i swojej rodziny, musiał stamtąd wyjechać" ${ }^{30}$.

Wszechobecne ubóstwo popychające ludność do migracji1 (niejednokrotnie także reemigracji) również tutaj generowało takie destrukcyjne zjawiska społeczne jak bezdomność, analfabetyzm, przemoc, sieroctwo oraz nierząd. Polski historyk Maciej Kozłowski przybliżając szacunkowe dane z lat 1890-1913 pisze, że z austriackiej Galicji oraz Bukowiny wyjechało około

\footnotetext{
26 Do kwestii tej powrócę w dalszej części artykułu [S.W.-M.].

27 W 1772 w wyniku pierwszego rozbioru Polski powstało Królestwo Galicji i Lodomerii wraz z Wielkim Księstwem Krakowskim i Księstwami Oświęcimia i Zatora. W praktyce była to prowincja i kraj koronny na terenie Galicji, która nieformalnie składała się z Galicji Zachodniej (stolica w Krakowie) i Galicji Wschodniej (stolica we Lwowie).

${ }_{28}$ Wchodząca w skład imperium habsburskiego ziemia galicyjska graniczyła z imperium rosyjskim, była - jak pisze Jarosław Hrycak - prowincją austriacką, o którą [...] toczyło się ostre współzawodnictwo między Habsburgami i Romanowami”. Zob. J. Hrycak, Prorok we własnym kraju. Iwan Franko i jego Ukraina (1856-1886), przeł. A. Korzeniowska-Bihun, A. Wylegała, Warszawa 2010, s. 6.

${ }^{29}$ Jarosław Hrycak pisze: „W 1888 roku polski ekonomista i przedsiębiorca Stanisław Szczepanowski wydał książkę Nędza Galicyi, której tytuł odzwierciedlał sytuację w Galicji w oczach całej Europy. Szczepanowski wyliczył, że przeciętny Galicjanin pracuje za ćwierć, je za połowę Europejczyka. Oprócz ,nędzy galicyjskiej” znane były ,galicyjskie wybory” jako symbol politycznej korupcji i nadużywania władzy, „tarnopolska moralność” jako eufemizm oznaczający oszustwa, oraz ,galicyjski hrabia” jako synonim samozwańca. [...] W mniemaniu Wiednia oraz oświeconej niemieckojęzycznej publiki, Galicja była „na wpół Azją”, „ziemią niedźwiedzi”, ,austriacką Syberią”. Zob. J. Hrycak, op. cit., s. 18.

30 J. Hrycak, op. cit., s. 17.

31 Zob. M. Pollack, Cesarz Ameryki. Wielka ucieczka z Galicji, Wołowiec 2017.
} 
700-800 tysięcy Ukraińców. Do prac sezonowych wyjeżdżało rocznie blisko 100 tysięcy osób ${ }^{32}$. Tomczyk z kolei, powołując się na prace ukraińskiego etnografa Wołodymyra Hnatiuka dodaje, że w monarchii habsburskiej bywały wsie ukraińskie, w których pozostawały niemal same kobiety i dzieci, bo mężczyźni wyjechali „za chlebem”33. Nie trudno zgadnąć, że w takiej sytuacji kobiety (a także dzieci) były wyjątkowo łatwym łupem handlarzy żywym towarem. Galicja dzieliła w tym zakresie los innych skolonizowanych ziem Europy Środkowo-Wschodniej, skąd zazwyczaj werbowali oni swoje ofiary. Obszarem ich działania oczywiście mógł być każdy kraj, jednak skupiali się na tych terenach, gdzie administracja i policja były mało skuteczne i podatne na korupcję, społeczeństwo niezamożne, słabo wykształcone, wewnętrznie skonfliktowane, a stopień wiedzy na temat „,białego niewolnictwa” nikły. Nierząd kwitł więc najmocniej, jak dowodzą badacze, podczas zaborów i dotykał przedstawicieli wszystkich skolonizowanych narodów ${ }^{34}$. Narody pozbawione opieki własnego państwa skazane były na politykę eksterminacyjną, której jednym z obliczy było przedmiotowe traktowanie i wykorzystanie. Handlarze - pod pozorem pomocy w pozyskaniu pracy zarobkowej - masowo wysyłali ubogie dziewczęta do odległych domów publicznych Europy i Ameryki, szczególnie Ameryki Południowej ${ }^{35}$.

Badacze odnotowują, że w Galicji Wschodniej, podobnie zresztą jak i we wschodnich guberniach Królestwa Polskiego, największy odsetek kobiet zajmujących się nierządem (jako ofiary) stanowiły kobiety pochodzenia żydowskiego, zaś mężczyźni pochodzenia żydowskiego stanowili największy odsetek wśród sutenerów ${ }^{36}$. Nie należy też zapominać o niechlubnej roli ko-

32 M. Kozłowski, Między Sanem a Zbruczem. Walki o Lwów i Galicję Wschodnia 19181919, Kraków 1990, s. 64.

33 R. Tomczyk, Rusinki (Ukrainki) w austriackiej Galicji.., op. cit., s. 104.

34 Zob. R. Antonów, Drogi hańby..., op. cit., s. 10-14.

35 „Według dostępnych danych (Jayme Brener „Jerusalem Report”, 1966) do Brazylii pierwszy statek z młodymi Żydówkami dotarł w 1867 roku. Przypłynęło na nim 69 wschodnioeuropejskich prostytutek. Do 1913 roku w centrum Rio de Janeiro działało 431 burdeli. Właścicielami połowy byli Rosjanie, Austriacy, Niemcy, Polacy, a nawet Rumuni. Prawie wszyscy pochodzenia żydowskiego". Zob. M. Kozerawska, J. Podolska, Piranie czekaja na kadisz, „Wysokie obcasy”, 22.01.2007 [w:] „Wysokie Obcasy” 2021, [źródło internetowe:] https:// www.wysokieobcasy.pl/wysokieobcasy/1,96856,3859153.html?disableRedirects=true, dostęp: 10.02.2020

36 Zob. A. Jakubczak, „Pogrom alfonsów” w Warszawie 1905 roku w świetle prasy żydowskiej, „Studia Judaica” 2015, nr 2 (36), s. 341-342. Aleksandra Jakubczak pisze: „Począwszy od lat osiemdziesiątych XIX w. społeczeństwo żydowskie zmagało się ze wstydliwym problemem poważnego zaangażowania polskich Żydów w organizację handlu żywym towarem oraz kontrolowanie rynku usług seksualnych (prostytucja, sutenerstwo) w wielu krajach na świecie. Tysiące młodych kobiet pochodzenia żydowskiego, głównie z małych sztetli - często pod przymusem lub podstępem - były wywożone $\mathrm{z}$ ziem polskich, przede wszystkim ze wschodnich guberni Królestwa Polskiego i wschodniej Galicji, do domów publicznych w Buenos Aires, Sao 
biet w przemyśle handlu żywym towarem. Oprócz mężczyzn trudniących się pozyskiwaniem „towaru”, po prowincji podróżowały również kobiety zwane „rajfurkami” ${ }^{37}$. Zdobywając zaufanie ofiar drobnymi prezentami i stosownym wyglądem, nęciły młode kobiety ,intratną" ofertą pracy w domu publicznym $^{38}$. Nieproporcjonalnie duże zaangażowanie ludności żydowskiej w handel żywym towarem przyczyniło się do utrwalenia w potocznej świadomości stereotypu Żydów czerpiących zyski z nierządu. Mieszkańcom Galicji z pewnością na długo zapadł w pamięci obraz Żyda - sutenera po wspominanym już wcześniej procesie z 1892 - kiedy to sądzono 27 sutenerów i handlarzy kobietami. Jak pisze Ryszard Tomczyk, ,wszyscy [oni - S.W.-M.] byli Żydami i Żydówkami galicyjskimi. Tej żydowskiej grupie przestępczej udowodniono sprzedaż do domów publicznych w Turcji, Egipcie i Indii 29 kobiet (panien i mężatek w wieku od 15 do 23 lat), w tym 9 było Żydówkami, pozostałe to Polki i Rusinki. Proces odbił się szerokim echem nie tylko w Galicji, ale i w Europie" $"$ ? .

Warto dodać, że stereotyp związany z uwikłaniem ludności żydowskiej w proceder nierządu przetrwał czasy zaborowe i funkcjonował przez cały okres międzywojenny. W latach 20. i 30. XX wieku w propagandzie antysemickiej pojawi się Żyd sportretowany jako szatan pochylony nad aryjską kobietą ${ }^{40}$. Jak pokazują dokumenty tamtego czasu, zajęcie sutenerstwa i stręczycielstwa nie było wyłącznie domeną Żydów. Do przestępczej działalności prowincjonalnego półświatka włączali się mężczyźni (nierzadko też kobiety) innych narodowości, i nie tylko o najniższym statusie społecznym ${ }^{41}$. Ukra-

Paulo, Nowym Jorku, Konstantynopolu, Johannesburgu czy londyńskim East Endzie, gdzie zmuszane były do uprawiania prostytucji. Handlem żywym towarem zajmowała się głównie żydowska mafia działająca pomiędzy Europą a innymi kontynentami aż do lat dwudziestych $\mathrm{XX}$ w. O znaczeniu ziem polskich w tym haniebnym przedsięwzięciu świadczy też nazwa mafii - „Warszawa”. W Argentynie i Brazylii obecność żydowskich prostytutek z Polski była aż tak widoczna, że z czasem la polaca (hiszp. 'Polka') stało się synonimem prostytutki”.

37 Rajfurka - kobieta prowadząca dom publiczny. W 1889 r. aż 75\% domów rozpusty prowadziły żydowskie madamas. Zob.: A. Jakubczak, op. cit., s. 343. Patrz także: J. Sikorska-Kulesza, Handel kobietami..., s. 243;

38 D. Dulak, op. cit., s. 67.

$39 \quad$ R. Tomczyk, Rusinki (Ukrainki) w autriackiej Galicji.., op. cit., s.103.

40 M. Kozerawska, J. Podolska, Piranie czekaja na kadisz..., op. cit.

41 Uwagę na ten fakt zwraca Iwanna Czerczowych, autorka artykułu Вдома але без дому: служниці в родинах украӥнської інтелігенції Галичини зламу XIX - XX століть, która pisze: „Дискурс інших цікавим чином позбавляв відповідальності своїх, що робили можливою практику проституції всередині імперії. «Домашня проституція», в яку жінок могли вочевидь втягувати силоміць, парадоксальним чином не викликала також ревного занепокоєння з боку влади. I це при тому, що безперечною була роль чоловіківклієнтів із середніх і вищих соціальних верств, які активно підтримували проституцію, користуючись послугами повій. [...] Дискурс про міжнародну секс-торгівлю був пов'язаний 3 іміджем Австро-Угорщини. Факт, що багато повій на Близькому Сході чи в Америці 
ińska badaczka Iwanna Czerczowych zauważa, że problemu ówczesnej prostytucji nie można rozpatrywać wyłącznie w uproszczonym schemacie winy przypisanej ,innym” czy też „obcym”. Proceder nierządu organizowany był niejednokrotnie przy współudziale tzw. „swoich”, których należy utożsamiać nie tylko z miejscową władzą, utrwalonymi stosunkami społecznymi, ale również najbliższym otoczeniem, np. pracodawcami czy rodziną ${ }^{42}$. Wśród wykorzystywanych kobiet i dzieci ${ }^{43}$ znajdowały się przedstawicielki różnych grup

мало австрійське громадянство шкодив імперському престижу. Особливо у контексті тогочасних австрійсько-турецьких відносин, і змаганнях у контролі над Південною Європою”. Zob. I. Черчович, Вдома але без дому: служниці в родинах української інтелігенції Галичини зламу XIX - XX століть, [w:] „Україна модерна. Український інтелектуальний часопис", [źródło internetowe:] http://uamoderna.com/md/cherchovych-domestic-service, dostęp: 10.01.2020. Fakt udziału tzw. „swoich” w procederze nierządu potwierdzają też raporty przysyłane do metropolity Szeptyckiego. Zob. А. Шептицький, Листи польських товариств, спілок, комітетів охорони здоров'я, Крайової шкільної ради та ін. у Варшаві, Кракові, Познані до Шептииького А. про діяльність, ЦДІА України, м. Львів, фонд нр 358, опис 1, справа 111.

42 Augustyn Wróblewski w artykule z 1909 r. pt. Przytutki dla upadtych kobiet pisał: „Na drogę upadku [kobiety] spycha zwykle pan, władca, przełożony, właściciel domu, gospodarz, fabrykant. Przyczyna upadku bywa zależność służbowa kobiety”. Cyt za: R. Antonów, Drogi hańby..., s. 27. Z kolei Stanisław Pozner w publikacji z 1907 r. pt. Nad otchłania (w sprawie handlu żywym towarem) informował o patologicznym zjawisku sprzedawania żon przez niezadowolonych z pożycia małżeńskiego mężczyzn. Zob. S. Pozner, Nad otchłania (w sprawie handlu żywym towarem, [w:] R. Antonów, Drogi hańby..., s. 69-104. O zjawisku pozbywania się z domu dziewcząt pisze również Jurij Wynnyczuk, wskazując na degradację moralną, upadek wartości rodzinnych. W opisywanych przez niego zeznaniach dziewcząt lwowskich trudniących się prostytucją na pierwszym miejscu podawane były złe stosunki rodzinne. Dziewczęta często skarżyły się na ojczyma, macochę, konflikt z przyrodnim rodzeństwem lub też rodzica, częściej matkę, która chcąc uniknąć romansu córki z nowym mężem, oddawała nieletnią dziewczynę handlarzom żywego towaru. Zob. Ю. Винничук, Таємниці львівського дна. (за мемуарами й матеріалами полічії та львівської преси початку XX cm.), cz. I, II, III, [w:] https://zbruc.eu/node/27795, dostęp: 15.07.2019.

43 Opierając się na materiałach źródłowych Jolanta Sikorska-Kulesza, podaje, że w XIX wie$\mathrm{ku}$ „obok bardziej [...] niż kiedykolwiek urozmaiconych form prostytucji heteroseksualnej rozwijała się zorganizowana prostytucja dziecięca i homoseksualna, z których słynęły zwłaszcza Londyn, a na początku XX w. i Berlin. Stare instytucje - domy publiczne - nabierały nowego charakteru". Zob. J. Sikorska-Kulesza, Zło tolerowane..., s. 6. Z polskich raportów (Polskiego Komitetu Walki z Handlem Kobietami Dziećmi) prowadzonych w latach 30. XX wieku również wynika, że niebagatelny odsetek kobiet uprawiających nierząd wchodziło na drogę tego procederu jeszcze $\mathrm{w}$ wieku dziecięcym. W dokumencie czytamy, że jeden z czechosłowackich funkcjonariuszy policji w latach 1920-28 prowadził badania nt. wieku, w którym rejestrowane kobiety (627 przypadków) zaczęły uprawiać nierząd. Z jego obliczeń wynikało, że ok. 4 procent kobiet rozpoczęło nierząd między 13-14 rokiem życia, a 27 procent przed ukończeniem 17 lat. „Co się zaś tyczy pierwszych przeżyć seksualnych, to raport podaje, że 3 procent prostytutek miało je między 8 a 9 rokiem życia, a 30 procent przed ukończeniem 13 lat". Przytoczone dane drogą nieoficjalną miały zostać dostarczone do Sekretariatu Ligi Narodów, która zaangażowała się w walkę z handlem żywym towarem. Komentatorzy podkreślali, że prowa- 
narodowościowych. Na ternie Galicji Wschodniej były to oczywiście wspomniane Żydówki, ale również Rusinki, Polki ${ }^{44}$, choć z pewnością można też było znaleźć prostytutki przyznające się do innych narodowości. Ich obecność w Galicji była skutkiem masowej wówczas migracji. Trudno nie podzielać słów Pawła Smoleńskiego, który twierdzi, że cuchnąca Galicyjska nędza była taka sama dla Polaków, Rusinów, Żydów czy innych narodowości ${ }^{45}$. Brutalnie wypychała $\mathrm{z}$ domów rodzinnych ubogie galicyjskie dziewczęta bez względu na ich przynależność narodową czy wyznaniową, nęcąc je możliwością znalezienia lepszego życia, i podstępnie wpychała w brudne lupanary. Trzeba zauważyć, że kobiety sprzedawane były nie tylko na zagranicznym runku prostytucji, trafiały też na „rynek rodzimy”, do większych miast polskich ${ }^{46}$ oraz stolicy regionu - Lwowa, który - by użyć słów współczesnego prozaika Jurija Wynnyczuka - wprost „kipiał od prostytucji”"47. Uznany ponoć w Bremie

dzone badania obejmowały liczbę kobiet, które osiągnęły pełnoletność w czasie I wojny światowej lub tuż po niej, a zatem w warunkach ekonomicznych i ,psychologicznych”, jak pisano, „anormalnych”. Zob. Wynik ankiety Ligii Narodów w sprawie metod rehabilitacji dorostych prostytutek, [w:] А. Шептицький, Листи польських товариств, спілок, комітетів охорони здоров'я, Крайової икільної ради та ін. у Варшаві, Кракові, Познані до Шептицького А. про діяльність, ЦДІА України, м. Львів, фонд нр 358, опис 1, справа 111. Z kolei Stefan Raczyński, autor publikacji na ten temat z 1930 r. pisał: „Obok handlu kobietami rozpowszechnił się jeszcze przed wojną światową handel dziećmi do krajów Ameryki środkowej i południowej, polegający na oddawaniu dziewczynek do pracy fizycznej, a potem - w miarę dorastania - do domów rozpusty, chłopców zaś - do pracy na plantacjach, częstokroć w warunkach nieludzkiego traktowania". Stefan Raczyński, Handel kobietami i dziećmi, [w:] R. Antonów, Drogi hańby..., s. 153. Fakty te znajdują potwierdzenie w korespondencji metropolity Szeptyckiego.

44 Opierając się na zgromadzonych materiałach policyjnych J. Wynnyczuk pisze, że w rejestrze policji lwowskiej (stan na 31 grudnia 1904 r.) figurowało 488 prostytutek. W 1906 r. było ich 392. Można się spodziewać, że oficjalna liczba nie pokrywała się z rzeczywistym stanem, który był zdecydowanie wyższy, ale można przypuszczać, że liczby mówiące o pochodzeniu narodowym oraz wyznaniu miały odzwierciedlenie w stanie faktycznym. Dodatkowo wyznanie świadczyło o pochodzeniu. Wynnyczuk zauważa, że na 316 zarejestrowanych dziewcząt to chrześcijanki, zaś 76 przyznawało się do wyznania mojżeszowego. Wśród chrześcijanek 103 zadeklarowało przynależność do obrządku greckokatolickiego, co wskazuje na ich ruskie czy też ukraińskie pochodzenie. Protestantek nie odnotowano. Z pewnością największą liczbę stanowiły Polki, chociaż były też prostytutki z Moraw, Czech, Bukowiny i Węgier. Zob. Ю. Винничук, Таємниці львівського дна. (за мемуарами й матеріалами поліиії та львівської преси початку XX cm.), op. cit.

$45 \quad$ W swojej recenzji książki Martina Pollaka, Cesarz Ameryki. Wielka ucieczka z Galicji Paweł Smoleński pisze: „Martin Pollack napisał reportaż fantastyczny. O nędzy, upokorzeniu, podłości, wyzysku zamkniętych w formułowaniu ,galicyjska bieda”. [...] Dzięki pisarstwu Pollacka nie tylko wiemy, jak cuchnęła galicyjska nędza, taka sama dla Polaków, Rusinów, Żydów, Słowaków. Wiemy również, że powinniśmy dziękować Bogu za przywilej późnego urodzenia”. $46 \quad$ Największe ośrodki prostytucji skupiały się w dużych miastach, takich jak Wilno, Warszawa, Katowice, Łódź, Kraków. Zob. D. Dulak, Handel ludźmi..., op. cit. s. 68.

47 Jak pisze Wynnyczuk, we Lwowie na początku XX stulecia istniało 16 koncesjonowanych domów publicznych, które działały pod nadzorem policji. Mając na uwadze, że przemysł pro- 
w 1905 r. (podczas kongresu poświęconemu problemowi handlu kobietami) za Sodomę monarchii habsburskiej, ustępować miał - jak pisze Wynnyczuk - tylko Budapesztowi ${ }^{48}$. Proceder nierządu kwitł również w większość galicyjskich miast i miasteczek (m.in. Stanisławowie ${ }^{49}$, Przemyślu, Jarosławiu, Złoczowie, Tarnopolu) posiadających $\mathrm{z}$ reguły status miejscowości garnizonowych. Wynnyczuk - korzystając z dokumentu epoki w postaci materiałów śledczych zdobytych na początku XX wieku przez polskiego dziennikarza i prozaika Stanisława Brandowskiego - podjął niewygodny temat ukraińskiej przeszłości w cyklu artykułów pod znamiennym tytułem $Z$ historii ukraińskiego dna. Z pewnością mogłaby to być „historia dna” kilku innych narodów zamieszkujących etnicznie pstrą Galicję Wschodnią.

Z treści publikacji dowiadujemy się o ciemnej stronie życia miasta, gdzie istniał ogromny popyt na usługi seksualne świadczone w oficjalnych lupanarach, jak i nieoficjalnych miejscach rozpusty: od zamożnych domów prywatnych po brudne uliczki przedmieścia, dworzec i zacienione parkowe aleje. Czytamy o pożądanej wręcz usłudze polegającej na „odnawianiu cnoty", którą we Lwowie miała wykonywać tajemnicza kobieta o przydomku „fabrykantka cnoty”. Poznajemy historię życia lwowskich prostytutek oraz austriackie przepisy legalizujące prostytucję ${ }^{50}$. Lwowską innowacją na skalę imperium, jak miał twierdzić Brandowski, były „,prostytutki dyskretne”, tzn. kobiety oficjalnie wykonujące zawód kelnerek czy też kasjerek w kawiarniach lub pensjonatach, które uprawiały nierząd nieoficjalnie, więc nie podlegały obowiązkowi rejestracji i regularnym kontrolom lekarskim. Jeśli wierzyć Brandowskiemu, to najczęściej one były nosicielkami chorób wenerycznych, którymi zarażały całe oddziały stacjonującej w mieście armii.

Sugestywne opisy galicyjskiego przemysłu prostytucji zawarte $\mathrm{w}$ treści publikacji Wynnyczuka wydają się korelować z inicjującym niniejszą publikację fragmentem powieści Jerzego Pilcha. Zacytowany fragment - odnoszący się do wyimaginowanego miejsca w bałkańskim Plamenogradzie - mógłby być doskonałym dokumentem epoki oddającym atmosferę większości miast usytuowanych w Europie Środkowo-Wschodniej końca XIX - początku

stytucji kwitł również poza oficjalnym rejestrem, należy się spodziewać, że liczba ta byłą dużo większa. Zob. Zob. Ю. Винничук, Таємниці львівського дна..., op. cit.

48 Co ciekawe, w imperium rosyjskim taką rolę pełnić miała - jak przekonuje Wynnyczuk - Warszawa, która ponoć ustępowała pod względem prostytucji jedynie Sankt Petersburgowi. Zob. Zob. Ю. Винничук, Таємниці львівського дна, ор. cit.

49 Dziś. Frankivs'k.

50 Zgodnie z treścią publikacji Wynnyczuka prostytutki winny być poddane rejestracji i stałemu dozorowi lekarskiemu. Rejestr nie mógł obejmować dziewcząt poniżej 14-go roku życia oraz kobiet zamężnych. Prostytutki nie spełniające tych warunków, miały być odsyłane pod opiekę krewnych. 
$\mathrm{XX}$ wieku ${ }^{51}$. O ich środkowoeuropejskim charakterze z pewnością decydowało położenie geograficzne, ale również polityczne, które przekładało się na odpowiedni społeczno-kulturowy ład tej części Europy. Nie będzie więc chyba zbyt dużym nadużyciem stwierdzenie, że o środkowej czy środkowo-wschodniej europejskości świadczyły tutaj - a może lepiej byłoby użyć słowa przypominały - wymienione przez Pilcha punkty centralne większości prowincjonalnych przestrzeni miejskich w państwie Habsburgów: hotel, ratusz, burdel, koszary, lazaret. Wszakże żołnierz miał strzec najdalszych rubieży imperium. Nieodzownym elementem urbanistycznego układu był więc widok munduru różnej rangi, a przy nim kobiety lekkich obyczajów, oczywiście zgodnie z zasadą: im dalej od centrum tym niższa ranga. Dotyczyło to zarówno żołnierskich epoletów, jak i statusu prostytutek. Miało przełożenie na awanse i status społeczny tak w całym wielkim austro-węgierskim organizmie państwowym, jak i w wąttych organizmach poszczególnych prowincjonalnych miejscowości. Najlepiej sytuowani mężczyźni, w tym żołnierze wysokiej rangi spotykali się $\mathrm{z}$ damami do towarzystwa $\mathrm{w}$ hotelach $\mathrm{i}$ domach publicznych $\mathrm{w}$ centrum miasta. Bywalcami peryferyjnych hoteli, pensjonatów i domów publicznych znajdujących się na obrzeżach miast byli przedstawiciele niższych warstw społecznych, studenci oraz żołnierze. Najniższą rangę zajmowały prostytutki dworcowe, uliczne i parkowe taką też przyciągały klientelę. Ten schemat uwidacznia się w powieści Pilcha, taki też rodzaj zależności opisuje w serii swoich publikacji Wynnyczuk.

Zawarte w obu tekstach informacje, należy oczywiście traktować z właściwym dystansem. Z pewną rezerwą warto też podchodzić do przywoływanych przez Wynnyczuka liczb. Ukraiński pisarz swoje rozważania nt. ukraińskiej nieobyczajności opiera głównie na podstawie dokumentu osobistego, dokumentów śledczych oraz artykułów prasowych, a więc materiałów obarczonych pewnym subiektywizmem (w przypadku ego-dokumentu) czy też być może obarczonych pewną manipulacją z uwagi na chęć osiągniecia odpowiednia sukcesu (w przypadku dokumentów śledczych) czy wrażenia (w przypadku materiałów prasowych). Jednak nawet jeśli „,pikantne” treści z Historii ukraińskiego dna potraktujemy wyłącznie w kategoriach anegdotycznej opowieści, to nie ulega wątpliwości, że opisywany przez ukraińskiego

\footnotetext{
${ }^{51}$ Autor cytatu - polski współczesny pisarz Jerzy Pilch - oczywiście nie należy do świadka epoki. Pilch znany jest $\mathrm{z}$ opowieści o ciągłym poszukiwaniu miłości życia, a co za tym idzie, regularnym zanurzaniu się w uciechach cielesnych. W powieści Portret młodej Wenecjanki, z której pochodzi zaczerpnięty cytat, wyczuwamy odautorskie zafascynowanie frywolną atmosferą dawnej prowincji wschodniej. Proza Pilcha wyraźnie wpisuje się w estetykę postmodernizmu propagującego zjawisko karnawalizacji, preferującego świat na opak i „doceniającego" temat nieobyczajności. Czas powstania utworu zdradza, skąd taka dosłowność wypowiedzi, bezpruderyjny zachwyt wyrażony w opisie miejsca i wreszcie wyrażony wprost w jego puencie: „Chryste Panie, jadę tam!”. Zob. J. Pilch, Portret młodej Wenecjanki, Kraków 2017, s. 89.
} 
pisarza schemat zależności funkcjonujący w procederze nierządu (jak i wskazanie na skalę problemu niezależnie od rzeczywistych liczb) zbieżny jest z relacjami zawartymi w publikacjach dokumentarnych, traktujących o problemie handlu żywym towarem na przełomie XIX-XX w. oraz nagłaśniających potrzebę jego zwalczania. Zbieżny jest również z informacjami na ten temat zawartymi w archiwalnym zbiorze dokumentów Andrzeja Szeptyckiego, które odnoszą się już do pierwszych dekad XX w.

\section{Z ARCHIWALNEGO MAGAZYNU INFORMACJI O EPOCE}

Już z oceny zewnętrznej korespondencji, tj. liczby dokumentów, tytułów, katalogu adresatów oraz dat widniejących na przesyłkach adresowanych do metropolity Szeptyckiego wynika, że proceder handlu żywym towarem nie zniknął po upadku państw centralnych. Bezsprzeczne sprzyjały mu warunki wojennego chaosu i biedy. Zwracała na to uwagę Maria Kobylińska, polska katolicka działaczka na rzecz walki z handlem kobietami i dziećmi. W swojej edukacyjnej publikacji z 1914 r., zatytułowanej: Handel żywym towarem a Katolickie Towarzystwo Opieki Dworcowej, pisała: „Można słusznie powiedzieć, że wiek dwudziesty jest dla dziewcząt wiekiem niewolnictwa" ${ }^{52}$. Problem handlu żywym towarem ,kwitt” w latach około wojennych, nie przestał być realnym problem społecznym także w Drugiej Rzeczpospolitej. Szczególnie mocno przejawiał się w pierwszych latach funkcjonowania młodego państwa, które odziedziczyło po czasach zaborowych niechlubną spuściznę w postaci dobrze rozwiniętej sieci handlarzy ludźmi, złej sytuacji gospodarczej, niskiego statusu kobiet, słabego poziomu świadomości społecznej, wynikającego z ówczesnego poziomu oświaty, i wreszcie deprawacji moralnej społeczeństwa ${ }^{53}$. Należy się spodziewać, patrząc na wcześniejsze statystyki, że czynniki te uwidaczniały się najmocniej w dzielnicach dotychczas najbardziej zacofanych. Naiwnie byłoby sądzić, że ominęły dzielnicę galicyjską. O tym, że tak się nie stało świadczą liczne dokumenty czasu w postaci raportów i sprawozdań organizacji zajmujących się walką z procederem nierządu, dokumentując jednocześnie ich zaangażowanie w naprawę sytuacji, także w Galicji.

O skali zjawiska nieobyczajności i destrukcyjnych jego konsekwencjach ponoszonych przez wszystkie narody, również naród ukraiński, który po I wojnie światowej znalazł się w granicach państwa polskiego, świadczą informacje zawarte $\mathrm{w}$ archiwalnej korespondencji. Jej ramy czasowe przypadają na lata 1930-1937, jednak w treści listów znaleźć można również od-

52 M. Kobylińska, Handel żywym towarem a Katolickie Towarzystwo Opieki Dworcowej, [w:] R. Antonów, Drogi hańby..., op. cit., s. 144.

53 D. Dulak, Handel ludźmi..., op. cit., s. 66. 
niesienia do czasów wcześniejszych. Dokumenty potwierdzają, że w II RP problem nierządu, w przeciwieństwie do czasów zaborowych, nie był legalizowany. Wręcz przeciwnie, państwo polskie oficjalnie wytoczyło walkę „białemu niewolnictwu" już na początku lat 20., nie ograniczając się wyłącznie do prasowych doniesień, publikacji artykułów, sprawozdań czy monografii. Dość szybko bowiem walka ta przybrała odpowiednie ramy instytucjonalne. Najważniejsze zadania w tym zakresie realizował Główny Urząd Emigracyjny przy Ministerstwie Spraw Zagranicznych oraz Ministerstwo Opieki Społecznej. Jednym z istotnych osiągnięć było roztoczenie opieki nad emigrantami (szczególnie najuboższymi), co niemal wzorcowo zostało zrealizowane na terenie województwo lwowskiego oraz w samym Lwowie w latach 20-30. $\mathrm{XX}$ wieku, przy niebagatelnym zaangażowaniu przedstawicieli miejscowych grup narodowościowych - Polaków, Ukraińców, Żydów. Stolica dawnej Galicji Wschodniej w okresie międzywojennym była - jak pisze Stepan Kaczara$\mathrm{ba}^{54}$ - epicentrum ruchu emigracyjnego z Ukrainy Zachodniej i jednocześnie największym ośrodkiem migracyjnym w państwie. Przez miasto przetaczała się fala migrantów z województw lwowskiego, stanisławowskiego, tarnopolskiego oraz południowo-wschodnich powiatów Wołynia.

$\mathrm{W}$ stolicy regionu, podobnie jak $\mathrm{i} \mathrm{w}$ ościennych miastach, stworzono szereg polskich, ukraińskich i żydowskich towarzystw sprawujących opiekę nad emigrantami. „Organizacje te prowadziły aktywną pracę informacyjną, walczyły z nielegalną działalnością agentów kampanii żeglugowych, nawiązywały ścisłe kontakty z ośrodkami imigracyjnymi za granicą. Z inicjatywy i przy współudziale towarzystw emigracyjnych zbudowano Dom Emigracyjny we Lwowie (1930), który zajął się opieką nad emigrantami. Przesiedleńcy mogli tu na jakiś czas zatrzymać się, uzyskać niezbędne informacje o warunkach przesiedlenia do innych państw, podpisać umowę o pracy sezonowej, kupić bilety na pociąg czy statek" ${ }^{55}$. Mimo, że Kaczaraba pisząc o organizacji opieki nad emigrantami, nie wspomina o problemie nierządu, to nie ulega wątpliwości, że praca nad wprowadzeniem ruchu migracyjnego w zorganizowane i legalne ramy (dodajmy: praca ponad podziałami narodowościowymi i konfesyjnymi ${ }^{56}$ ) przyczyniała się również do ograniczania handlu żywym towarem, co z pewnością doskonale rozumieli zarówno decydenci na szczeblu państwowym, jak i regionalnym. Na marginesie tylko można dodać, że świadomość ta, jak i liczne sukcesy wiązane $\mathrm{z}$ działalnością powołanych instytucji, nie były niestety w stanie przezwyciężyć problemów finansowych,

\footnotetext{
54 С. Качараба, Участь львів'ян в організачії опіки над емігрантами (1921-1939), [w:] Lwów: miasto, społeczeństwo, kultura: studia z dziejów Lwowa, t. 5: Ludzie Lwowa, Kraków 2005, s. 397-407.

55 С. Качараба, Участь львів'ян в організації опіки над емігрантами (1921-1939), ор. cit., s. 407.

$56 \quad$ Ibidem, s. 404-406.
} 
które szybko doprowadziły większość lwowskich towarzystw emigracyjnych do bankructwa ${ }^{57}$.

Równolegle z działaniami państwa na polu zwalczania handlu żywym towarem szeroko zakrojone prace prowadził Polski Komitet Walki z Handlem Kobietami i Dziećmi ${ }^{58}$, z którym - jak się przekonujemy - metropolita Szeptycki współpracował chętnie i regularnie. Komitet był stałym korespondentem duchownego w sprawie walki z procederem nierządu. Szeptycki w 1930 roku osobiście uczestniczył w VIII Międzynarodowym Kongresie Komitetów Zwalczania Handlu Kobietami i Dziećmi w Warszawie, gdzie wygłosił specjalny odczyt ${ }^{59}$. W kolejnych latach systematycznie otrzymywał od Komitetu raporty i sprawozdania, opisujące skalę i specyfikę zjawiska nierządu na terenie II RP oraz za granicą.

Jak pokazują dokumenty, Polska kładła szczególny nacisk na kwestię przeciwdziałania demoralizacji publicznej. Działacze w zakresie walki z handlem ludźmi $\mathrm{w}$ pierwszym rzędzie nagłaśniali potrzebę walki z pornografią, jako istotnym czynnikiem przyczyniającym się do wzrostu nierządu ${ }^{60}$. Wychodząc z założenia, że zmiana stosunków w ustrojach gospodarczo-społecznych następowała szybciej, aniżeli w poglądach moralnych ówczesnego społeczeństwa, stwierdzano, że wczesne wyjście kobiety z domu w poszukiwaniu zarobku, powojenny kryzys ekonomiczny i bezrobocie uzasadniały wzmożenie akcji opieki społecznej nad nieletnimi dziewczętami zagrożonymi moralnie. Mając na względzie fakt, że w dziedzinie opieki nad tymi ostatnimi trudno było rozgraniczyć akcję prewencyjną od akcji rehabilitacyjnej, oraz że działania w dziedzinie walki z prostytucją były niejednokrotnie walką z przestępczością, Polski

\footnotetext{
$57 \quad$ Ibidem, s. 406.

58 Komitet zrzeszał w charakterze członów 31 organizacji pozarządowych.

59 Zob. List do A. Szeptyckiego od Polskiego Komitetu Walki z Handlem Kobietami i Dziećmi z podziękowaniem za wygłoszenie przemówienia na VIII Międzynarodowym Kongresie Komitetów Walki z Handlem Kobietami i Dziećmi, [w:] А. Шептицький, Листи польських товариств, спілок, комітетів охорони здоров'я, Крайової шкільної ради та ін. у Варшаві, Кракові, Познані до Шептииького А. про діяльність, ЦДІА України, м. Львів, фонд нр 358, опис 1, справа 111 .

${ }_{60}$ Dzięki staraniom Polskiego Komitetu Walki z handlem Kobietami i Dziećmi, podczas IX Międzynarodowego Kongresu (1933 r, Berlin) podjęto rezolucję następującej treści: „Kongres zaleca organizowanie we wszystkich krajach komisji ekspertów, które na żądanie policji, władz sądowych i innych występowałyby z głosem doradczym w sprawach spornych, dotyczących pornografii i określały granice między działami naukowymi lub dziełami sztuki a pornografią.[...]" Zadaniem wskazanej komisji miała być walka z demoralizacją publiczną, ochrona młodzieży od zepsucia oraz wydawanie opinii o książkach i wydawnictwach. Tego typu komisje funkcjonowały również w innych krajach. Polska czyniąc starania o powołanie komisji, powoływała się na przykład Holandii, gdzie komisja pracowała już od roku 1930. Zob. А. Шептицький, Листи польських товариств, спілок, комітетів охорони здоров'я, Крайової икільної ради та ін. у Варшаві, Кракові, Познані до Шептицького А. про діяльність, ЦДІА України, м. Львів, фонд нр 358, опис 1, справа 111, с. 44.
} 
Komitet uważał że koniecznie należy zawiązać ściślejszą współpracę międzynarodową z Komitetami innych krajów w celu zdobycia większego doświadczenia i wypracowania wspólnych metod przeciwdziałania nierządowi. Podczas zagranicznych debat wykazywał dużą aktywność. Postulował np. poddanie pod dyskusję kwestię uznania przygotowania do handlu kobietami jako samoistnego przestępstwa obłożonego karą, co umożliwiłoby skuteczniejszą walkę z handlarzami żywym towarem. Czynił też starania, aby wprowadzić zakaz uprawiania nierządu przez osoby nieletnie, jak również zakazania - pod groźbą kary - korzystania z usług nieletnich, trudniących się prostytucją. Zaproponował także stworzenie wykazu zawodów, w jakich pracownicy, szczególnie młodociani mogliby być narażeni na demoralizację i dotknięcie problemem nierządu. Nagłaśniał również potrzebę roztoczenia opieki nad emigrantkami. Pozbawione opieki własnego państwa, słabo znające język i nieposiadające odpowiednich środków materialnych były łatwymi ofiarami stręczycieli ${ }^{61}$.

Oprócz realizacji głównego celu, jakim była walka z handlem żywym towarem kobietami i dziećmi, polski Komitet przyłączał się do głosu krajów, wskazujących na pilną potrzebę zwalczania szeroko rozpowszechnionych chorób wenerycznych ${ }^{62}$, które były pokłosiem prostytucji. Bazując na doświadczeniach polskich oraz europejskich i światowych, Komitet przysyłał metropolicie Szeptyckiemu własne opracowywania nt. rozwiązania problemów w zakresie handlu ludźmi na terenie Polski. Poświęcał specjalną uwagę sprawom rehabilitacji dziewcząt ,moralnie zaniedbanych a pragnących powrócić do normalnego życia", jak pisano. Komitet w tym celu intensywnie współpracował z Misjami Dworcowymi, które udzielały potrzebującym odpowiednich informacji oraz zajmowały się profilaktyką ${ }^{63}$. Ich sieć pokrywała

61 Zob. Sprawozdanie z działalności Polskiego Komitetu Walki z Handlem Kobietami i Dziećmi za okres 01.03.1933r. - 01/04.1935r., [w:] А. Шептицький, Листи польських товариств, спілок, комітетів охорони здоров'я, Крайової шкільної ради та ін. у Варшаві, Кракові, Познані до Шептииького А. про діяльність, ЦДІА України, м. Львів, фонд нр 358, опис 1, справа 111.

${ }_{62}$ W Polsce międzywojennej praktykowano dobrowolne leczenie chorób wenerycznych podobnie, jak w Belgii czy Wielkiej Brytanii. Jednak już Włochy faszystowskie stosowały bardzo surowe przepisy w tym względzie i choroba weneryczna uznawana była za przestępstwo, które podlegało karze, podobnie restrykcyjny system funkcjonował w Rosji Sowieckiej. Przymus leczenia stosowały Francja, Węgry, Czechosłowacja. Jak wynika z raportów tamtego czasu, źródła finansowania leczenia chorób wenerycznych bywały nader rozliczne, w większości pochodziły z budżetu państw, władz prowincjonalnych, departamentalnych czy samorządowych, zob. wyniki ankiety Ligi Narodów w sprawie rehabilitacji dorosłych prostytutek, [w:] А. Шептицький, Листи польських товариств, спілок, комітетів охорони здоров'я, Крайової шкільної ради та ін. у Варшаві, Кракові, Познані до Шептищького А. про діяльність, ЦДІА України, м. Львів, фонд нр 358, опис 1, справа 111.

${ }_{63}$ Misje Dworcowe zajmowały się tworzeniem schronisk, noclegowni, prowadziły też działalność profilaktyczną i resocjalizacyjną. W schroniskach uczono zawodu, prowadzono kursy dokształcające z zakresu szkoły powszechnej, pomagano w znalezieniu pracy. Misja Dwor- 
coraz większą liczbę miast Polski, w tym dawnej Galicji Wschodniej, której ziemie w nowym podziale administracyjnym II RP znalazły się w Małopolsce Wschodniej. Z nadsyłanych do metropolity Szeptyckiego opisów działalności Misji Dworcowych, dowiadujemy się o miejscach ich funkcjonowania, ich liczbie w miejscowościach z dużym odsetkiem ludności ukraińskiej (m.in. Lwów ${ }^{64}$, Stanisławów ${ }^{65}$, Kołomyja ${ }^{66}$, Brody ${ }^{67}$ ) oraz rozlicznych problemach,

cowa we Lwowie współpracowała ze schroniskiem w Brzuchowicach. Por. D. Dulak, Handel ludźmi..., op. cit., s. 70.

64 W 1934 r. przy Zarządzie Misji Dworcowej powstało we Lwowie schronisko pod wezwaniem Św. Katarzyny, przeznaczone dla moralnie zaniedbanych dziewcząt. Schronisko początkowo mieściło się w Brzuchowicach, następnie przeniesione zostało do miasta. Utrzymywało się z ofiar osób prywatnych, subwencji Komitetu i Zarządu m. Lwowa. Pracowało w stałym kontakcie z Komitetem, nadsyłając mu co miesiąc sprawozdania z działalności. Dziewczęta uczyły się tam gotowania, szycia, fryzjerstwa, haftu, pielęgniarstwa, rękawiczarstwa i guziczarstwa - pisano w raporcie. Niektóre z nich po ukończonych kursach otrzymywały możliwość zatrudnienia. Schronisko urządzało również spotkania świąteczne, na które zapraszane były dziewczęta $\mathrm{z}$ ulicy. Prowadzono w śród dziewcząt pracę edukacyjną, w postaci prelekcji i pogadanek. Raporty to nie tylko zbiór cyfr i suchych faktów, podają również, na zasadzie przykładu, rozliczne historie, z których wynika, że problem prostytucji dotykał również osoby nieletnie. Czytamy: „Znamienny jest fakt, że niedawno dwie starsze eks-prostytutki przyprowadziły do schroniska 14-letnią dziewczynkę, którą trzymały u siebie „kątem” pilnując, by się nie dostała na ulicę". W innym miejscu czytamy, że staraniem Komitetu przyjęta została na wychowanie do domu im. Prezydentowej Michaliny Mościckiej 9-letnia sierota zarażona chorobą weneryczną. Dziewczynka, ze szpitala, gdzie przebywała na kuracji, dostała się do schroniska, ale tam, ze względu na jej młody wiek i towarzystwo eks-prostytutek, uznano jej pobyt za niewskazany", zob. Sprawozdanie z działalności Polskiego Komitetu Wali z Handlem Kobietami i Dziećmi za okres od 01.04.1935 do 31.03.1936 r., [w:] А. Шептицький, Листи польських товариств, спілок, комітетів охорони здоров'я, Крайової шкільної ради та ін. у Варшаві, Кракові, Познані до Шептииького А. про діяльність, ЦДІА України, м. Львів, фонд нр 358, опис 1, справа 111.

${ }_{65}$ „W województwie Stanisławowskim - czytamy - daje się dotkliwie odczuć bezrobocie i biedę. Utarł się tam zwyczaj, że dziewczęta wiejskie nie mając pieniędzy na podróż koleją, wędrują piechotą od miasta do miasta w poszukiwaniu pracy. Wskutek tego wypadki nasuwające podejrzenie handlu żywym towarem i stręczenia do nierządu, zdarzają się tam liczniej niż w innych częściach kraju. Zjawisko to zaobserwowano już w latach poprzednich. W roku 1934 inspektorka Komitetu zbierała m.in. i w Stanisławowie informację o niejakim B.F., rzekomo lekarzu, który projektując, jak twierdził, założenie sanatorium w Polsce, angażował młode dziewczęta na posady sanitariuszek, uwarunkowane jednak tym, że wyjadą uprzednio do Ameryki dla przeszkolenia w jego szpitalu. Innym znowu dziewczętom proponował małżeństwo, również połączone z wyjazdem do Ameryki. Znajomości swoje zawierał na ulicy, w kawiarniach, w kinach. Działalność jego była dość znana w Małopolsce Wschodniej, ale ponieważ nie zdążył wywieźć żadnej ofiary za granicę, a przygotowania do „handlu” nie są uznawane za karalne, proces przeciwko niemu został umorzony”, zob. Sprawozdanie z działalności Polskiego Komitetu Wali z Handlem Kobietami i Dziećmi za okres od 01.04.1935 do 31.03.1936 r., [w:] А. Шептицький, Листи польських товариств, спілок, комітетів охорони здоров'я, Крайової икільної ради та ін. у Варшаві, Кракові, Познані до Шептицького А. про діяльність, ЦДІА України, м. Львів, фонд нр 358, опис 1, справа 111. 
zazwyczaj natury finansowej i kadrowej. Istotnym wsparciem dla działalności Misji Dworcowych było powołanie w 1925 roku kobiecej Policji Państwowej, której głównym zadaniem była walka $\mathrm{z}$ handlem kobietami i dziećmi, prostytucją, interwencje wobec nieletnich $\mathrm{z}$ tytułu ich przestępczości, praca w izbie zatrzymań dla nieletnich, których zatrzymywano z powodu żebractwa, włóczęgostwa, porzucenia przez bliskich ${ }^{68}$.

W połowie lat 30 . Komitet zintensyfikował działania na polu informacyjno-propagandowym. Drukował broszurki pt: Stan walki z nierzadem, Czy istnieje handel żywym towarem na Wschodzie?, oraz ulotki ostrzegawcze Do Emigrantek, których wydrukowano 130.000 celem stałego ich dostarczania Misjom Dworcowym, Ekspozyturom Syndykatu Emigracyjnego i biurom pośrednictwa pracy. Komitet poszukując wsparcia w rozpropagowaniu informacji na temat zagrożeń płynących z handlu ludźmi, zwrócił się o wsparcie do biskupów, w tym do metropolity Szeptyckiego, z prośbą o poparcie dla działań i dostarczenie ulotek do parafii. Dzięki przychylności biskupów rozesłano ponad 11 tysięcy egzemplarzy.

W 1936 r. do wiadomości Ekscelencji przedstawiona została też słynna publikacja dr Stefana Okęckiego (członka Prezydium Komitetu) zatytułowana Walka z pornografia w Polsce. Metropolita nie wahał się poprosić o jej przekład na język ukraiński. Autor publikacji wyraził zgodę na tłumaczenie i ponowne wydanie broszury. W kraju na szeroką skalę rozwinęły się również badania związane z przestępstwem handlu ludźmi, pojawiły się odpowiednie rozwiązania prawne ${ }^{69}$. Do akcji przyłączyła się prasa, szczególnie feministyczna, korzystano ze zdobyczy techniki takich, jak radio, w którym emitowano audycje edukacyjne, czy cieszące się coraz większą popularnością kino, gdzie wyświetlano filmy edukacyjno-propagandowe. Akcja skierowana była do wszystkich obywateli kraju. Na poziomie centralnym państwo polskie wydawało się nie stosować podziałów narodowościowych w realizowanym programie zapobiegania ,procederowi hańby”. Jednak Ukraińcy nie mogli

\footnotetext{
${ }_{66}$ Kołomyja - miasto położone blisko granicy rumuńskiej, również odnotowywało problem handlu żywym towarem. Jednak założenie placówki Misji Dworcowej było tam z przyczyn technicznych, jak pisano, trudne do wykonania, więc problemem zajęła się radna miejska pełniąca funkcję członka-korespondenta Komitetu, zob. А. Шептицький, Листи польських товариств, спілок, комітетів охорони здоров'я..., ор. cit.

${ }_{67}$ W Brodach inspektorka zbierała informacje w sprawie S.J., który jako rzekomy konwojent emigrantów pozostawił własnemu losowi na dworcu kolejowym w Katowicach pewną kobietę namówioną uprzednio wraz kilkoma innymi do wyjazdu z nim do Francji. Jak wynika z dokumentu, poszukiwany człowiek był niebezpiecznym przestępcą, który po zastrzeleniu policjanta uciekł do Paryża, i tam jako „opiekun” polskich emigrantów trudnił się również stręczycielstwem. Zob. Sprawozdanie z działalności Polskiego Komitetu Wali z Handlem Kobietami i Dziećmi za okres od 01.04.1935 do 31.03.1936 r., op. cit.

68 Ibidem.

$69 \quad$ R. Antonów, Drogi hańby..., op. cit., s. 30-46.
} 
być w satysfakcjonującym stopniu jego bezpośrednim odbiorcą. Audycje i filmy emitowane były w języku polskim i ze względów ekonomicznych pozostawały niemalże całkowicie poza zasięgiem ubogiej ludność ukraińskiej zamieszkującej obszary wsi i małych miast, z których wywodził się znaczący procent ofiar handlu żywym towarem w II RP. Dużo większy zakres oddziaływania mogła mieć prasa, ale tutaj znów pojawiała się bariera finansowa lub językowa. Niebagatelną przeszkodą były też mocno wyczuwalne podziały na tle narodowościowym. Trudno sobie wyobrazić, aby ukraińskie kobiety, zwłaszcza mieszkanki małych, prowincjonalnych miejscowości, czytały polski kobiecy „Bluszcz” czy socjalizujące „Wiadomości Literackie”. Na szpaltach zaś najbardziej dostępnych i popularnych tytułów ukraińskich w Galicji takich, jak „Diło”, „Meta”. czy nawet wydań kobiecych, jak np. „Żinocza Dolia" - które często same borykały się z problemami finansowymi - wskazana problematyka nie znajdowała - patrząc na skalę problemu i potrzeb - należytego rezonansu. XX-wieczne badania nad ukraińskim ruchem kobiecym, który w latach 30 . XX wieku przeżywał fazę rozkwitu, wydają się pokazywać, że barierą większą niż finansowa były względy mentalne. Znawczyni historii ukraińskiego ruchu kobiecego - Marta Bohaczewska-Chomiak zauważa, że nawet jeśli w latach 30. XX wieku w ukraińskiej prasie kobiecej coraz częściej pochylano się nad sprawami związanym z seksualnością, to artykuły nie wychłodziły poza wąską tematykę związaną z problemami zdrowia i higieny i sprowadzane były do ,prowincjonalnych” wywodów o charakterze dydaktycznym. Publikacji wprost traktujących o chorobach wenerycznych (w tym o zagrożeniach płynących z procederu prostytucji) oraz o zaburzeniach seksualnych było niewiele. Uwagę ukraińskich działaczek wciąż pochłaniały problemy natury ekonomicznej, bytowej i oświatowej.

Na szpaltach czasopism kobiecych pojawiała się dyskusja na temat konfliktu pokoleń, a w latach 30., żywą reakcję kobiecej publicystyki wzbudzała walka o prawa kobiet pracujących. Tematem stale aktualnym w okresie międzywojennym była też kwestia patriotyczna, którą w drugiej połowie lat 30 . podsycała ideologia nacjonalistyczna. Ukraińska badaczka sugeruje, że brak oficjalnego, szerszego zainteresowania problematyką seksualności (w tym, jak należy mniemać, także problemem nierządu) ze strony ukraińskiego ruchu kobiecego wynikał z presji, jaką na ukraińskich feministkach mieli wywierać niektórzy ukraińscy działacze polityczni oraz „samozwańczy rzecznicy Cerkwi katolickiej”, zarzucając działaczkom „erotomaństwo” i „propagandę wolnej miłości" ${ }^{\text {". }}$. Dodatkowo problematyki konkurencyjnej wobec zjawiska nierządu z pewnością dostarczały ukraińskim działaczkom gorące doniesienia z zagranicy czy też nieustanny polsko-ukraiński konflikt polityczny w kra-

\footnotetext{
70 М. Богачевська-Хомяк, Білим по білому. Жінки в громадському житті Украйни 1884-1932, Київ 1995, s. 239-240.
} 
ju. Konflikt, który po latach liderka ówczesnego ruchu kobiecego, niezwykle zaangażowana w bieżące wydarzenia polityczne szefowa Związku Ukrainek - Milena Rudnycka - nazwie „,permanentną zimną wojną" "'11. W obliczu takich wydarzeń politycznych jak np. pacyfikacje ${ }^{72}$, a przede wszystkim sztucznie wywołany przez władze komunistyczne Wielki Głód na Ukrainie Radzieckiej w latach 30., który pochłonął miliony istnień, sprawa handlu żywym towarem schodziła na plan dalszy. W tej sytuacji jeszcze bardziej należy - jak się wydaje - docenić działalność Andrzeja Szeptyckiego, który nie tylko zdawał sobie sprawę z zagrożeń płynących ze wszystkich destrukcyjnych zjawisk społecznych, w tym z infekującego młody naród ukraiński procederu nierządu, ale rozumiał też finansowe, instytucjonalne oraz mentalne ograniczenia społeczności ukraińskiej w Galicji. Stąd też jego żywe zainteresowanie problematyką handlu ludźmi oraz aktywne wsparcie dla działalności Polskiego Komitetu Walki z Handlem Kobietami i Dziećmi, oraz instytucji z Komitetem współpracujących.

\section{ZAKOŃCZENIE}

Przywoływane w artykule opracowania oraz dokumenty epoki dowodzą, że tak powszechny w Europie drugiej połowy XIX - początku XX wieku problem nieobyczajności nie ominął również etnicznie zróżnicowanej Galicji Wschodniej. Bezsprzecznie był on zjawiskiem niosącym ze sobą realne zagrożenia natury moralnej i fizycznej także dla ludności ukraińskiej, która stanowiła największy odsetek mieszkańców tego regionu zarówno w czasach austrowęgierskich, jak i w okresie Drugiej Rzeczpospolitej, w składzie której znalazła się po 1918 roku cała dzielnica galicyjska. Będąc pokłosiem ogromnej biedy, zacofania i masowej migracji, zjawisko nieobyczajności przybierało charakter wyjątkowo brutalnego procederu przestępczego, jakim był handel żywym towarem, przede wszystkim kobietami i dziećmi. Stąd też zawarty we fragmencie prozy Jerzego Pilcha odautorski zachwyt wyczuwalny w opisie „typowej” prowincjonalnej, austrowęgierskiej miejscowości (tym bardziej wyrażony okrzykiem: „Chryste Panie, jadę tam!”) z pewnością byłby niezrozumiały dla tysięcy ofiar ,galicyjskiej nędzy” i wypaczonych stosunków społecznych we wschodniej prowincji państwa Habsburgów.

\footnotetext{
71 Zob. М. Рудницька, Статmі, листи, документи, red. М. Богачевська-Хомяк, М. Дядюк, Я. Пеленський, Львів 1998, s. 350.

72 Chodzi o karne pacyfikacje organizowane przez władze polskie w latach 20. i 30. wobec ludności polskiej w Galicji w odwecie za działania sabotażowe i terrorystyczne podziemia ukraińskiego.
} 
Treść przedstawionych materiałów pokazuje, że proceder nierządu w jednakowym stopniu wyniszczający wszystkich poszkodowanych, bez względu na ich przynależność narodową czy konfesyjną, kwitł w okresie zaboru austriackiego, był też istotnym problemem społecznym w II Rzeczpospolitej. Państwo polskie, dostrzegając jednak realne zagrożenia wynikające $\mathrm{z}$ handlu ludźmi, rozpoczęło zinstytucjonalizowaną walkę z tym zjawiskiem. Jedną $\mathrm{z}$ ważniejszych organizacji zajmujących się przeciwdziałaniem nierządowi był Polski Komitet Walki z Handlem Kobietami i Dziećmi, który do współpracy zaprosił metropolitę Kościoła greckokatolickiego - Andrzeja Szeptyckiego. Dokumenty epoki w postaci archiwalnej korespondencji ukraińskiego duchownego z polskimi instytucjami dobroczynnymi pokazują, że był on słusznie postrzegany jako jeden z ważniejszych ukraińskich partnerów we współpracy na tym polu. Szeptycki doskonale rozumiał, że traumatyzujące zjawiska, dla których Jurij Wynnyczuk w serii swoich publikacji na ten temat użył trafnego określenia „ukraińskie dno”, są jedną z głównych przyczyn degradacji młodego narodu ukraińskiego, który u progu XX wieku próbował realizować swoje marzenia państwotwórcze. Swoimi działaniami na rzecz poprawy jakości życia ówczesnych Ukraińców galicyjskich metropolita próbował zrekompensować im brak opieki własnego państwa. Nie spychał jednak wstydliwej prawdy o ukraińskich problemach społecznych w sferę niepamięci, wręcz przeciwnie, starał się walczyć z mentalnymi stereotypami na temat patologii funkcjonujących wśród jego wiernych. Otwarcie upominał się o milczące ukraińskie ofiary niewolnictwa, ubóstwa, sieroctwa, przemocy zarówno na zjazdach Komitetu Wali z Handlem Żywym Towarem kobietami Dziećmi, jak i w licznych listach pasterskich. Z lektury korespondencji oficjalnej i prywatnej wynika, że zakres jego osobistego zaangażowania w walkę ze omawianymi zjawiskami wykraczał poza granice działalności informacyjnej i propagandowej. Obejmował też budowę lecznicy dla ubogich we Lwowie, oddziały sierocińców, ochronek, domy dla samotnych matek, szkoły i sanatoria. Stąd też zachowany w archiwum materiał, będący przyczynkiem do podjęcia tematu ${ }^{73}$ o galicyjskiej nieobyczajności końca XIX stulecia i pierwszych dekad XX wieku może być traktowany jako istotny magazyn informacji o nadawcy i odbiorcy, środowisku, w jakim żyli, słowem o epoce ${ }^{74}$. Dokumenty bowiem przemawiają zwłaszcza tam, gdzie literatura (podmiotu i przedmiotu) nie może unieść skali problemu. Nawet jeśli niemoc ta wynika nie tyle z niewydolności słowa literackiego, ile z ograniczeń mentalnych, politycznych czy ekonomicznych.

Tematu z pewnością niewyczerpanego i wymagającego dalszych badań uściślających.

M. Czermińska, Autobiograficzny trójkąt..., op. cit., s. 253. 


\section{BIBLIOGRAFIA}

\section{Archiwalia}

Šeptic'kij Andrej. Listi pol's'kih tovapistv, spilok, komitetiv ohoroni zdorov'â, Krajovoï škil'noï radi ta ìn. y Varšavì, Krakovi, Poznanì do Šeptic'kogo A. pro diâl'nist'. Central'nij deržavnij ìstoričnij arhìv Ukraïni, m. L'viv. Fond № 358. Opis 1. Sprava 111 [Шептицький Андрей. Листи польських товариств, спілок, комітетів охорони здоров'я, Крайової шкільної ради та ін. у Варшаві, Кракові, Познані до Шептицького А. про діяльність. Центральний державний історичний архів України, м. Львів. Фонд № 358. Опис 1. Справа 111].

Barkov Illâ. 2018. İnstitut prostitucï̈v mistah pivdennoïUkraïniv 1843-1914 pp. Zaporìžžâ: Zaporìz'kij nacìonal'nij unìversitet. W: http://phd.znu.edu.ua/page/dis/01_2018/

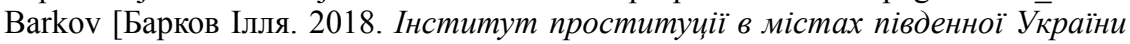
в 1843-1914 pp. Запоріжжя: Запорізький національний університет. W: http:// phd.znu.edu.ua/page/dis/01_2018/Barkov]. Dostęp: 10.02.2020.

Vinničuk Ûrìj. 2014. Taêmnici l'vìvs'kogo dna (za memuarami j materìalami polìciï ta l'vivs'koï počatku XX st.). „Zbruč”. Cz. I, II, III. W: https://zbruc.eu/search/node/\%D0 $\%$ A2\%D0\%B0\%D1\%94\%D0\%BC\%D0\%BD\%D0\%B8\%D1\%86\%D1\%96\%20\%D0 $\%$ BB $\%$ D1\%8C $\%$ D0\%B2\%D1\%96\%D0\%B2\%D1\%81\%D1\%8C\%D0\%BA\%D0\% BE\%D0\%B3\%D0\%BE\%20\%D0\%B4\%D0\%BD\%D0\%B0 [Винничук Юрій. 2014. Таємниці львівського дна (за мемуарами й матеріалами поліџї та львівської преси початку XX cm.). „Збруч”. Cz. I, II, III. W: https://zbruc.eu/search/node/\%D0 $\%$ A2\%D0\%B0\%D1\%94\%D0\%BC\%D0\%BD\%D0\%B8\%D1\%86\%D1\%96\%20\%D0 $\%$ BB $\%$ D1\%8C\%D0\%B2\%D1\%96\%D0\%B2\%D1\%81\%D1\%8C\%D0\%BA\%D0\%B E\%D0\%B3\%D0\%BE\%20\%D0\%B4\%D0\%BD\%D0\%B0]. Dostęp: 15.07.2019.

Bogačevs'ka-Homâk Marta. 1995. Bilim po bilomu. Žinki v gromads'komu žitti Ukraïni 1884-1932. Kiïv: Libìd' [Богачевська-Хомяк Марта. 1995. Білим по білому. Жінки в громадському житті України 1884-1932. Київ: Либідь].

Kačaraba Stepan. 2005. Učact' l'viv ân v organizaciï opiki nad emigrantami (1921-1939). W: Lwów: miasto, społeczeństwo, kultura. Studia z dziejów Lwowa. T. 5: Ludzie Lwowa. Red. Karolczak K. Kraków: „Wydawnictwo Naukowe Akademii Pedagogicznej”: 397-407 [Качараба Степан. 2005. Участь львів'ян в організачії опіки над емігрантами (1921-1939). W: Lwów: miasto, spoteczeństwo, kultura. Studia $z$ dziejów Lwowa. T. 5: Ludzie Lwowa. Red. Karolczak K. Kraków: „Wydawnictwo Naukowe Akademii Pedagogicznej": 397-407].

Kravčuk Andrìj (Red.). 1988. Mitropolit Andrej Šeptic'kij. Žittâ i diâl'nist'. Dokumenti i materiali [Кравчук Андрій (Red.). 1988. Митрополит Андрей Шептицький. Життя і діяльність. Документи і матеріали 1899-1944. Т. II: Церква і суспільне питання. Cz. 1: Пастирське вчення та діяльність. Львів: Видавництво отців василіан «Місіонер»].

Rudnic'ka Mìlena. 1998. Statti, listi, dokumenti. Red. Bogačevs'ka-Homâk M., Dâdûk M., Pelens'kij Â. L'vìv: İnstitut ìstoričnih doslìdžen' [Рудницька Мілена. 1998. Cmammi, листи, документи. Red. Богачевська-Хомяк М., Дядюк М., Пеленський Я. Львів: Інститут історичних досліджень].

Čerčovič Ivanna. 2018. Vdoma ale bez domu: služnicì v rodinah ukrä̈ns'koï inteligenciï Galičini zlamu XIX - XX stolit'. W: http://uamoderna.com/md/cherchovych-domestic-service [Черчович Іванна. 2018. Вдома але без дому: служниці в родинах української інтелігениї Галичини зламу ХІХ - ХХ століть. W: http://uamoderna. $\mathrm{com} / \mathrm{md} /$ cherchovych-domestic-service]. 
Adamkiewicz Sebastian. 2017. Najcudowniejszy wiek XIX?. W: https://histmag.org/Najcudowniejszy-wiek-XIX-14784. Dostęp: 10.02.2020.

Antonów Radosław (Oprac.). 2013. Drogi hańby. Piśmiennictwo polskie przełomu XIX i XX wieku o handlu ,żywym towarem”. Wrocław: Wydział Prawa, Administracji i Ekonomii Uniwersytetu Wrocławskiego.

Cimek Henryk. 2008. Przynależność Galicji (Małopolski) Wschodniej - w koncepcjach polskich klubów ludowych w 1919 r. „Polityka i Społeczeństwo” nr 5: 9-16.

Czermińska Małgorzata. 2000. Autobiograficzny trójkąt. Świadectwo, wyznanie i wyzwanie. Kraków: Universitas.

Dulak Dawid. 2016. Handel ludźmi w II Rzeczpospolitej. „Poliarchia” nr 2 (7): 59-76.

Hrycak Jarosław. 2010. Prorok we własnym kraju. Iwan Franko i jego Ukraina (18561886). Przekład: Anna Korzeniowska-Bihun, Anna Wylegała. Warszawa: Wydawnictwo Krytyki Politycznej.

Szulakiewicz Władysława. 2013. Ego-dokumenty i ich znaczenie $w$ badaniach naukowych. „Przegląd Badań Edukacyjnych” nr 16: 65-84.

Jakubczak Aleksandra. 2015. „Pogrom alfonsów” w Warszawie 1905 roku w świetle prasy żydowskiej. „Studia Judaica” nr 2 (36): 339-357.

Kozerawska Małgorzata, Podolska Joanna. 2007. Piranie czekaja na kadisz. „Wysokie obcasy". W: https://www.wysokieobcasy.pl/wysokieobcasy/1,96856,3859153. html?disableRedirects $=$ true.

Kozłowski Maciej. 1990. Między Sanem a Zbruczem. Walki o Lwów i Galicję Wschodnia 1918-1919. Kraków: Znak.

Łoś Stanisław. 2012. Sprawa ukraińska. Wybór i redakcja Marszał M., Wójtowicz S. Kraków: Ośrodek Myśli Politycznej.

Nowak Katarzyna. 2019. Dzieci rewolucji przemystowej. Kto naprawdę zbudowat wspótczesny świat? Kraków: Znak.

Nowak Magdalena. 2012. Szeptycki Roman Aleksander w zakonie Andrzej (1865-1944). W: Polski Stownik biograficzny. T. 48/2. Z. 197. Warszawa: Wydawnictwo Towarzystwa Naukowego Societas Vistulana: 216-224.

Nowak Magdalena. 2018. Refleksje o pracy badawczej nad monografia o metropolicie Andrzeju Szeptyckim. W: Biografistyka we współczesnych badaniach historycznych. Teoria i praktyka. Red. Kolbuszewska J., Stobieckiego R. Łódź: Wydawnictwo Uniwersytetu Łódzkiego: 149-163.

Pilch Jerzy. 2017. Portret młodej Wenecjanki. Kraków: Wydawnictwo Literackie.

Podraza-Kwiatkowska Maria. 2001. Symbolizm i symbolika w poezji Młodej Polski. Kraków: Universitas.

Pollack Martin. 2017. Cesarz Ameryki. Wielka ucieczka z Galicji. Wołowiec: Wydawnictwo Czarne.

Sikorska-Kulesza Jolanta. 2004. Zło tolerowane. Prostytucja w Królestwie Polskim w XIX wieku. Warszawa: Wydawnictwo „Mada”.

Szczepanowski Stanisław. 1888. Nędza Galicyi w cyfrach i program energicznego rozwoju gospodarstwa krajowego. Lwów: Gubrynowicz i Schmidt.

Szulakiewicz Władysława. 2013. Ego-dokumenty $i$ ich znaczenie $w$ badaniach naukowych. „Przegląd Badań Edukacyjnych” nr 16: 65-84.

ŚwistJulita.2020.Prostytucja-ryshistoryczny.W:http://www.racjonalista.pl/kk.php/s,4028/ k,2. Dostęp: 16.07.2020.

Tomczyk Ryszard. 2012. Rusinki (Ukrainki) w austriackiej Galicji. Między konserwatyzmem a radykalizmem. „Przegląd Zachodniopomorski” t. XXVII, z. 2: Kobieta w kulturze politycznej świata: 89-111. 
Wiśniewska Magdalena. 2013. Archiwum jako miejsce pamięci. „Archiwa - Kancelarie Zbiory" nr 4 (6): 137-148.

Szeptycka Zofia. 1993. Młodość i powołanie ojca Romana Andrzeja Szeptyckiego zakonu św. Bazylego Wielkiego: opowiedziane przez matke jego 1865-1892. Oprac. Bogdan Zakrzewski. Wrocław: Towarzystwo Przyjaciół Polonistyki Wrocławskiej.

\section{GALICYJSKA NIEOBYCZAJNOŚĆ KOŃCA XIX I PIERWSZYCH DEKAD XX WIEKU W ŚWIETLE WYBRANYCH DOKUMENTÓW EPOKI}

Streszczenie: $\mathrm{W}$ artykule został poruszony problem nieobyczajności drugiej połowy XIX i początku XX wieku na terenie Galicji Wschodniej. Nieobyczajność nazywana jest również nierządem, prostytucją, handlem żywym towarem kobietami i dziećmi, białym niewolnictwem. Powszechny na terenie Galicji Wschodniej proceder prostytucji nie był wynikiem dynamicznych procesów uprzemysłowienia czy spektakularnej urbanizacji jak w Europie Zachodniej. Wchodząca od 1772 r. w skład imperium Habsburgów Galicja właśnie z uwagi na prowincjonalny oraz graniczny charakter skazana była na polityczny konflikt wewnętrzny, zastój gospodarczy i zacofanie. Wszechobecne ubóstwo, popychające ludność do migracji, generowało takie destrukcyjne zjawiska społeczne, jak bezdomność, przemoc, sieroctwo oraz nierząd. Galicja dzieliła w tym zakresie los innych skolonizowanych ziem Europy Środkowo-Wschodniej, skąd zazwyczaj werbowali swoje ofiary handlarze żywym towarem. Problem nie zniknął po upadku państw centralnych, stanowił też poważne wyzwanie dla władz II Rzeczpospolitej, w skład której w 1918 r. weszła Galicja Wschodnia. Inspiracją do napisania tekstu była znaleziona w Archiwum Historycznym miasta Lwowa korespondencja metropolity Kościoła greckokatolickiego Andrzeja Szeptyckiego oraz cykl artykułów ukraińskiego prozaika Jurija Wynnyczuka pt. Z historii ukraińskiego dna.

Słowa klucze: nieobyczajność, nierząd, handel żywym towarem kobietami i dziećmi, białe niewolnictwo, Galicja Wschodnia, literatura ukraińska, korespondencja archiwalna, dokumenty epoki, Andrzej Szeptycki

\section{ГАЛИЦЬКА НЕПРИСТОЙНІСТЬ КІНЦЯ ХІХ ТА ПЕРШИХ ДЕСЯТИЛІТЬ ХХ СТОЛІТТЯ У СВІТЛІ ВИБРАНИХ ДОКУМЕНТІВ ЕПОХИ}

Резюме: Дана стаття торкається питання непристойності другої половини XIX - початку XX століття на землях Східної Галичини. Непристойність називають також проституцією, торгівлею людьми (перш за все жінками та дітьми) та білим рабством. Поширена на території Східної Галичини проституція не була результатом динамічних процесів індустріалізації або швидкої урбанізації, як в Західній Свропі. Через свій провінційний та прикордонний характер Східна Галичина, яка 31772 року стала частиною імперї Габсбургів, була приречена на внутрішній політичний конфлікт, а також стагнацію та економічну відсталість. Повсюдна бідність, що штовхає людей на міграцію, породжувала такі руйнівні соціальні явища, як безпритульність, насильство, сирітство та проституція. У цьому відношенні Галичина розділяла долю інших колонізованих земель Центрально-Східної Європи, звідки торговці людьми зазвичай вербували свої жертви. Після поразки Центральних держав проблема не 
зникнула і стала викликом для влади II Речіпосполитої, у складі якої Східна Галичина опинилася від 1918 року. Поштовхом для написання цієї статті стало листування митрополита та голови греко-католицької Церкви, віднайдене в Центральному державному історичному архіві міста Львова, а також низка статей українського письменника, Юрія Винничука, Таємниці львівського дна.

Ключові слова: проституція, торгівля людьми (жінками та дітьми), біле рабство, Східна Галичина, українська література, Андрей Шептицький 